\title{
Use of smartphone apps among library and information science students at South Valley University, Egypt
}

\author{
Prof. Dr. Essam Mansour \\ dr.essamman@gmail.com \\ DLIS, SVU \\ Egypt
}

\begin{abstract}
The purpose of this study is to investigate the use patterns and ownership of smartphone apps among students at the Department of Library and Information Science (DLIS) at the South Valley University (SVU), Egypt. This study may help faculty members and students, as well as DLISs in general and SVU's DLIS, in particular, to understand the nature and purpose of such use.
\end{abstract}

\section{Design/methodology/approach}

This study used quantitative research methodology in the form of a survey, which was undertaken from February to March 2015. The survey instrument was a self-administrated questionnaire, with a response rate 82.7 per cent $(441 / 533)$.

\section{Findings}

The findings of this study showed that smartphone users (82.7 per cent) at SVU's DLIS tended to be junior females. Smartphone non-users (17.3 per cent) tended to be also young females but primarily sophomores. The highest percentage of smartphone users had been using smartphones for four to five years, and the largest number of students was described to be advanced users who heard first about these mobile devices through friends and the Web. Most users had 21 to 25 apps. Social apps were the most popular and included Facebook, e-mail and Twitter. For professional purposes, students used smartphones more for communication purposes than learning purposes. Apps related to educational purposes included Google Mobile, Facebook, e-mail, Twitter, YouTube and Wikipedia Mobile. Students perceived most apps to be easy to use and useful to them. There were a number of uses for socializing including messaging, following the news and playing games. Students had mainly positive attitudes towards apps with a few negative concerns. Almost all students confirmed that they trust most apps. Barriers related to the use of apps included training and lack of awareness. Further research may be needed to specify the relationship between the students' use of these apps and their academic performance. The main tasks done on smartphone devices were mainly for socializing. Students indicated that popular tasks and activities, such as sending and receiving messages, following the news, making communications, making chat, making friends, finding specific information, finding general information, making discussion groups, playing games, completing class assignments, checking materials related to courses, doing business, seeking jobs, watching movies, listening to music and accessing library services are important tasks accomplished by them through the use of these devices. The current study indicated very positive attitudes towards the use of these apps. Student at least agree with the statement that smartphone apps allow for easy dissemination of information, provide too much information, increase the speed of finding information, help communication, convenient, secure, build confident and reduce paper use. However, a large number of students also at least agree with the statement that these apps are time consuming, intimidating, addictive, violate privacy, require high language and technical skills, harmful and frustrating. Almost all students confirmed that they are at least trustful in some apps, such as WhatsApp, e-mail, YouTube, Facebook, Flickr, Twitter and Viber. A large number of smartphone users surveyed in this study have been described to make excessive usage of social apps, such as communication apps, messaging/texting apps and social networking sites, which were at the forefront of use. Additionally, a large number of them adopted these devices, especially for communication purposes. The most used apps were Facebook, e-mail, Twitter, WhatsApp, YouTube and Viber. For professional 
purposes, students used smartphones more for communication purposes than learning purposes. However, some of the students were using some of apps related to educational purposes, such as Google mobile, Facebook, e-mail, Twitter, YouTube and Wikipedia mobile but not on a regular basis. Students perceived the use of e-mail app, Google mobile, Facebook app WhatsApp, Kik, Twitter, YouTube, Google maps, Viber, Line, Skype, Tango, Instagram, Flickr and Wikipedia mobile as at least fairly easy to them. Additionally, they perceived the use of e-mail app Google mobile, WhatsApp, Facebook, YouTube, Twitter, Viber, Instagram, Wikipedia mobile, Google maps, Kik, Skype, Line, Tango and Flickr as at least fairly useful to them, especially for the purpose socialization more than learning.

\section{Research limitations/implications}

This study focuses only on undergraduate library and information science students belonging to SVU's DLIS, Egypt. Any findings and conclusions resulting from this study are limited in scope to only SVU's DLIS's undergraduate students. The study does not contain a significantly large sample of a population from across Egypt to draw meaningful widespread conclusions indicative of such a larger population.

\section{Practical implications}

This study provides valuable insight into the use pattern of smartphones among a very important client group. It may serve as useful input to researchers who are interested in the study of mobile internet technologies (MITs), particularly in the education society.

\section{Originality/value}

Being the first study of its kind about university students in Egypt, it is considered a pioneering and a unique study among studies conducted in the field of ICTs and MITs, especially with this category of information users.

\section{Keywords:}

Smartphones, Education, Egypt, College students, Library and information science, Mobile internet technologies, Qena, South valley university

Type:

Research Paper 


\section{Introduction}

Smart phones are one of the most common technologies and devices accessed and used by a large number of people all over the world. They have become one of the main tools to get a quick access to information. "Smartphone is one [of] the most ubiquitous, dynamic and sophisticated trends in communication" (Alfawareh \& Jusoh, 2014, p. 321). According to the Radicati Group (2014), a technology market research firm, the number of worldwide mobile users, including both business and consumers, reached 5.674 billion users in 2014 and by the end of 2018; this number is expected to reach over 6.2 billion. "Roughly $84 \%$ of the world population will be using mobile technology by year-end $2018 "$ " (p. 2).

The role of smart phones is apparent in all aspects of life, particularly in politics and education. It appeared clearly in what is called "The Arab Spring", particularly in Egypt, where such devices were described to be the most important ways of communication among protestors inside and outside Egypt. In this regard, Duffy (2014) confirmed that "The smart phone helped cover the Arab Spring in a way that traditional journalism simply couldn't" (p. 53). In education, sharing the opinion with Chen and Denovelles (2013), the popularity of Mobile Internet Technologies (MITs), such as smart phones, tablets as well as e-book readers, among college students is noticeably increasing. A significant number of universities are using now mobile technologies and create mobile-optimized versions of their websites, or build stand-alone apps that can be downloaded from mobile app stores (Rellinger, 2011). Such devices and tools are playing a significant role in the academic life of college students. They help connect students to each other and connect to their instructors as well. Applications (apps), which run on these devices/tools let students not only consume, but also discover and create content (Dahlstrom, 2012). Despite the widespread use of smart phones, little is known about the ownership of such devices as well as their use by the population in general and students in particular (Yavari et al. 2009). Investigating the use of smart phones among students at the university level is very important because they tend to be among the first people trying to use new technology (Richard, 2013). The current study tries to investigate the ownership and use of such mobile devices among students enrolled in one of Egyptian library and information science schools.

\section{The purpose and significance of the study}

The main purpose of this study is to investigate the usage patterns and ownership of smart phone apps among students at the Library and Information Science (DLIS), the South Valley University (SVU), Egypt. Previous studies, such as Chiu, Dukic and Lo (2014), revealed that there is limited research about the use of Mobile Internet Technologies (MITs) by LIS students. The current research, therefore, may help faculty members and students as well at LISs in general and SVU's DLIS in particular understand the nature and purpose of such use. This study may serve as useful input to researchers who are interested in the study of MITs, particularly in the education society.

\section{The statement of the problem}

In the shade of the tremendous growth of smart phones, a very large number of previous studies showed that these mobile devices have been mostly used for communication and entertainment (Viticci, 2012). The Mobile Internet Technologies (MITs), especially smart phones, have been studied on a large scale, but research about the potential use of these devices among university students, especially at the undergraduate level, has still not gained such considerable attention by researchers, especially in the Arab countries, where Egypt is located. More research, therefore, is really needed to be conducted on this topic among such users to recognize how and why they use such kinds of devises whatever the reasons and purposes are.

\section{The objectives of the study}

The eight key objectives of this study are to: 
- Describe the demographic characteristics of smart phone users and non-user at SVU's DLIS.

- Describe the features of the use of smart phone apps by students at SVU's DLIS.

- Determine the ease and usefulness of using apps by smart phone users at SVU's DLIS.

- Determine which types of apps used most by smart phone users at SVU's DLIS.

- Determine which apps smart phone users at SVU's DLIS use for education and library-related activities?

- Determine tasks done on apps by smart phone users at SVU's DLIS.

- Determine the positive and negative aspects of using apps by smart phone users at SVU's DLIS?

- Identify constraints encountered by smart phone users and non-users at SVU's DLIS.

\section{Definitions of terms}

Smart phones

"Smartphone is a mobile phone running a complete operating system in a manner similar to a traditional computer, which offer advanced computing abilities and connectivity options. These features enable new kinds of mobile services that in turn shape the usage habits of smart phone users" (Alfawareh \& Jusoh, 2014, p. 321). They are used interchangeably with mobile phones, cell phones and feature phones. All are to some extent similar, but still different in terms of their capabilities. The smart phone has very advanced capabilities than the two others.

\section{Smart-phone Applications (apps)}

According to encyclopedia2.thefreedictionary.com, smart phone apps are defined as software applications that run on a mobile phone. These may include games, diaries, planners, maps and loads more. They range from Games, e-Book Readers, Navigation Software, Services providing news and weather feeds, to Apps allowing users to access Internet services, such as e-mail, Youtube, Facebook and other Social Networking Apps (UYS, et al., 2012).

\section{The Department of Library and Information Science (DLIS)}

According to its official site on the Web, DLIS founded in 2003 to build cadres specialized in library and information science to meet the needs of the various sectors, particularly in the Upper Egypt. In total, DLIS has 600 undergraduate students, of whom 523 as females and 77 as males. It has one associate professor, three assistant professors, three teaching assistants and seven tutors (DLIS, 2014).

\section{The South Valley University (SVU)}

According to its official site on the Web, SVU was established on January 2, 1995 by presendial degree No. 142. It covers a large area in the Upper Egypt distributing in three Governorates (Qena, Luxor, \& the Red Sea), and includes a total of 16 faculties and one Institute. The main campus of the SVU is located in Qena, which is $609 \mathrm{~km}$ south the capital "Cairo". As compared to its weight, SVU is committed to a big social service role in the region of the Upper Egypt. SVU is a vibrant, nationally recognized studentcentered research institution with an enrolment of 28173 in the Academic Year 2013/2014 and about 1377 faculty members (SVU, 2014).

\section{The Arab Republic of Egypt (ARE)}

Egypt is one of the oldest civilizations, with recorded history dating back to about $4000 \mathrm{~B}$. C. With a total area of about $386.662 \mathrm{sq} \mathrm{mi}$ and estimated population of 80,471.869 in 2010, Egypt is situated at the northeast of Africa on the Mediterranean Sea; Egypt is bordered to the West by Libya, to the South by Sudan, and to the East by the Red Sea and Israel (Infoplease, 2012).

\section{The limitation of the study}

This study focuses only on library and information science students, at the undergraduate level, particularly those are belonging to SVU's DLIS, Egypt. It does not cover any other disciplines or any 
other levels (graduates). Any findings and conclusions resulted from this study; are limited in scope to only SVU's DLIS's undergraduate students. Additionally, the study does not contain a significantly large sample of a population from across Egypt to draw meaningful widespread conclusions indicative of such a large population.

\section{The literature review}

Despite the extensive use of smart phone devices, little is known about their ownership and use by the general population and students (Yavari et al., 2009). The use of such kinds of mobile devices has largely helped students improve their access to current and reliable information sources. "Today, mobile phones have features that go far beyond text messaging and voice calls. They include Internet browsing, music (MP3) playback, memo-recording, personal organizer functions, e-mail, bulletin, cameras, infrared and Bluetooth connectivity. However, the ability of the mobile phones to offer a range of applications depends on the capability of individual mobile phones and the services available" (Anyanwu, Ossai-Onah and Nse, 2012, pp. 52-53).

In a chronological order, the researcher tried to review literature related to the use of these mobile devices by university students. For example, Alfawareh and Jusoh (2014) tried, through a survey approach, to explore the trends in the use of smart phones among university students $(n=324)$ at Najran University, Saudi Arabia. Findings revealed that a very large number of students owned smart phones and the majority of them were using smart phones as a regular mobile phone, as a computer connected to the Internet as well as a digital camera. Although a very large number $(91.69 \%)$ of students has used these devices to login to their academic portal, $66.89 \%$ of them never used them to record class lectures and $46.51 \%$ never used them for downloading materials related to class. Regarding the potential use of smart phone devices for educational purposes, Chen and Denovelles (2013) tried, through an online survey, to explore the access and use of these devices as well as barriers to the insertion of mobile technologies into the academic sphere. They surveyed 809 undergraduate and 133 graduate students at the University of Central Florida (UCF). They found that students' ownership of mobile devices were mainly a small mobile device, such as iPhone and Android, followed by a mobile tablet, such as as iPad, Android tablet and kindle Fire) and e-book reader, such as Kindle. The findings also revealed that students need more access to academic-friendly devices, such as tablets, and additional support to integrate mobile technologies for learning-related activates. Bomhold (2013) surveyed 75 students who enrolled in an introductory class in information literacy at a university in the Southern USA. He reached conclusion that students do use smart phone apps for more than communication and entertainment, where a significant number of them disclose using apps to find academic information on academic web sites using related search engines. White and Mills (2012) surveyed 403 Japanese university students regarding their adoption and use of smart phones, especially for language learning purposes. They found that students are increasingly adopting these mobile devices for a personal use, but they are still reluctant to use them for educational purposes. The study revealed that students' attitude towards the use of these devices for learning purposes have become more positive. Through an online survey, Song and Lee (2012) tried to investigate the ownership of mobile devices (smart phones, tablet PCs and e-readers) among 101 international students enrolled at the college of Business at the University of Illinois, USA, especially in the shade of the availability of mobile services introduced by academic libraries. It also revealed that although students were interested more in communication, they were also using mobile devices to access Social Networking Sites (SNSs), search for information and to have fun as well. Dresselhaus and Shrode (2012) conducted two surveys on the use of smart phones at Utah State University (USU), USA. The first survey was concerned about the use of USU's students (approximately 25,000 undergraduates and graduates) to determine why they use such devices as well as their interests in mobile access to the library collections and services. The second survey was directed to librarians to learn about libraries' current and future plans to launch mobile services. While results from the first survey helped to gain insight into where students stand regarding their use of mobile devices for academic activities in general and their 
desire for access to library services and resources in particular, resulted from the second survey gave an idea of the extent to which responding libraries offer mobile access, their future plans for mobile implementation and their opinions about how mobile technologies may be useful to library patrons. Anyanwu, Ossai-Onah and Nse (2012) conducted a survey on the potential use of smart phones for research purposes among undergraduate students in two polytechnic libraries in Nigeria. Findings showed that students using the polytechnic libraries were using their smart phones for research occasionally. The findings also revealed that students were pushed to use these mobile devices for some reasons, such as the lack of relevant information sources in libraries, saving of time and cost of moving to other libraries for research, low level of satisfaction derived from available resources as well as the lack of Internet facilities in libraries. However, barriers, such as the high cost of downloading some of online resources, incompatibility of software/formats of online resources as well as insecurity of sites, which causes damages to the phones, were identified as constraints encountered by students when using smart phones. Uys et al. (2012) tried to assess the usage of smart phone apps, specifically social networking apps, among students at a South African university who are using these apps. They tried to assess the frequency and intensity of the usage of apps. Findings showed that students spend an average of five hours per day on their smart phones communicating and interacting with others via SNSs, and remain online for about 16 hours per day. Students were found to use SNSs predominantly for Facebook, Facebook chat and Blackberry Messenger in order to update their profiles, chat with friends, and look at their friends' profiles and statuses. Through a cross-sectional survey, Jamal et al. (2012) tried to explore the pattern use of smart phones among 120 female medical students at Taibah University, Saudi Arabia. Findings revealed that $53.2 \%$ of students used smart phones daily. Only $13.3 \%$ of the students using smart phones found that they had a harmful effect on their academic performance. The study concluded that a substantial number of female medical students using smart phones reported possible health hazards, which might affect academic performance. Using a self administrated questionnaire, Yavari et al., (2009) conducted their study on the mobile phones used by 309 medical science students at the Yazd Medical Sciences University, Pakistan. Findings showed that students mostly used smart phones at home, followed by the street, classroom, during driving and in the library respectively. They reported that location wise, the use of cell phones at home was $87.2 \%$, followed by street (79.6\%), classroom (37.6\%), during driving (18.6\%) and in the library (17.8\%) respectively. Abdul Karim, Darus and Hussin (2006) tried to explore the use of mobile phone services in the educational environment as well as the perception of university students on the use of mobile phone in library and information services. Data collected from 206 undergraduate students from two academic faculties in a Malaysian public university to investigate the perception of students about the use of wireless phones. Findings showed that students' perceptions on the application of wireless hand services in the context of library and information services were found to be very positive

Regarding the use pattern of smart phones by library and information science students, there was a serious attempt made by Adomi (2006) who tried, through a systematic random sampling technique, to investigate the usage patterns of these mobile devices among 110 students at the Department of Library and Information Science, Delta State University, Nigeria. Findings revealed that a majority of the students were using mainly apps for making communication with their parents/relatives/friends as well as sending and receiving messages. Family matters, followed by finance and academic matters constitute the most conversation topics on the smart phones. Frequent network/call failure, followed by the high cost of recharge cards/airtime, limited area of coverage as well as interconnectivity problems were the most significant challenges faced by DLIS's students at Delta State University when using smart phone apps.

\section{Academic use of smart phones}

According to Rhema and Sztendur (2013), "Mobile phones are seen as a key means for improving access to education" (p. 215). Such mobile devices in general and smart phones in particular establish a potential 
for ubiquitous learner engagement that is often referred to as 'learn anything at anytime and anywhere (Sakamura \& Koshizuka, 2005). There are really a lot of ways to learn using mobile technologies, which are described as a gateway to tools and resources. Such technologies make learning more personalized and connect the instructor with his/her students and reduce any gaps that may arise between them.

\section{Advantages of smart phones in education}

According to Bae and Kim (2014), the biggest advantage of the use of smart phones in education is that learning can be accomplished anywhere and at any time without any limit. It can create an effective learning environment for instructors as well as students. Compared to other mobile devices, such as tablets and laptop computers, smart phones have the following advantages:

- They are small and lightweight as they can easily be carried by anyone, anytime and anywhere.

- $\quad$ They are not too much expensive due to fewer materials that are associated with their use.

- $\quad$ They run on smaller amounts of power than other devices like laptop and desktop computers.

- $\quad$ They have more supportive ways, such as Bluetooth and/or Internet connectivity.

- $\quad$ They're very engaging, so learning can last for a long time (Ecycle Best, 2015).

\section{Students' use of smart phone apps}

"College students are more likely to be innovators or early adopters of new information technologies than the general population" (Nelson, 2006, p. 6). Smart phone apps enable students to access a variety of electronic media and information in a convenient way. According to Seilhamer, Chen and Sugar (2013), there are significant factors that make mobile learning more attractive to college students, such as convenience, flexibility, engagement and interactivity. Results from the ECAR research study on students suggest that many undergraduate students bring their own digital devices to college, favouring small and portable ones, such as smart phones and tablets. Mobile technologies are playing an increasingly important role in college students' academic lives. They connect users to the world instantly, heightening access to information and enabling interactivity with others. According to Chiu, Dukic, and Lo (2014), the following are the most unique benefits of using mobile technologies for teaching and learning:

- They are relatively inexpensive, easily carried and mobiled.

- They allow students to learn at their convenient time at "anywhere and at anytime", without any restrictions by the physical classroom.

- They let students interact virtually, and this could encourage them to develop their social and skills.

- They are a great challenge for libraries, as they provide libraries with various opportunities to extend their collections and services by enabling access to their end-users in their most convenient way.

With the help of the mobile phone-enabled technologies, smart phones are considered the most appropriate and suitable ways and means to host all web applications in a pocket-sized computing device to be easily carried and accessed by the user. According to Baghianimoghadam et al. (2013), mobile phones have severe adverse effects on students' academic achievement. They may be used in the classroom to engage students, access real-time feedback and answer questions anonymously.

\section{Research questions}

Based on its objectives, this study was designed to answer the eight following research questions:

RQ1. What are the demographic characteristics of smart phone users and non-users at SVU's DLIS?

RQ2. What are the features of the use of smart phones by students at SVU's DLIS (period of use, experience, first hearing about apps, location, the number of smart phones owned, smart phone brand and the number of apps accessed)?

RQ3. Which types of apps do students at SVU's DLIS use most?

RQ4. Which apps do students at SVU's DLIS use for education and library related activities? 
RQ5. What are the characteristics (ease and usefulness of use) of the apps' use by students at SVU's DLIS?

RQ6. Which tasks do students at SVU's DLIS on smart phone apps?

RQ7. What are the positive and negative aspects of the students' use of apps at SVU's DLIS?

RQ8. What are the most significant barriers that affect both use and non-use of apps by students at SVU's DLIS?

\section{Research methodology}

This study was designed to describe the usage pattern and ownership of smart phone apps among students at SVU's DLIS, Egypt. In nature, the descriptive research involves collecting data in order to answer questions or to test hypothesis concerning the current status of the subject of the study. It can provide very valuable data (Gay, 1992). This descriptive method is useful for investigating a variety of educational problems. Typical descriptive studies are concerned with the assessment of attitudes, opinions, demographic information, conditions, and procedures. Descriptive data are usually collected through a questionnaire survey, interviews, or observation. This study employed quantitative research methodology in the form of a survey, which was undertaken from February to March 2015. According to Kerlinger (1986), the survey research is a useful tool for educational fact-finding and a means by which a great deal of information can be obtained from the population of the study. The survey instrument of this study was a self-administrated questionnaire, which was designed to collect data from participants. The survey form was deeply reviewed and approved by a panel of experts consisting of one professor and two associate professors who are interested in Mobile Internet technologies (MITs), social media as well as those who are teaching courses in the field of library and information sciences. The validity and reliability of the survey were checked through a pilot test implemented in the same department (SVU's DLIS) before the actual distribution. The questionnaire consisted of twenty-five questions, which were divided into nine sections. All the questions were closed-ended questions, but the last question (\#25) was an openended one. The researcher opted to rely largely on closed-ended questions because they were more suited to the nature of the study's population that is not familiar much with surveys, and may be less willing to state their feelings or opinions through hand written open-ended questions. The first section consisted of three questions, which are related to the most basic demographic characteristics (gender, age \& the class standing) of DLIS' students. The second section (two questions) was about the students' use/non-use of smart phones as well as barriers to not use such kinds of mobile technologies. The third section (just one question) was about if students use or do not use smart phone apps. The fourth section (ten questions) tried to explore the characteristic use of smart phone apps by DLIS's students, such as the frequency of the use of apps, the use level, time spent, knowledge about apps, the number of smart phone devices owned as well as the number and type of apps accessed. The fifth section (just one question) was about the use of apps for education and library-related activities. The sixth section (just one question) was about tasks done with apps. The seventh section (five questions) was about the students' perceptions about the use of apps, such as how much they are easy, useful, trustful as well as their negative and positive aspects. The eighth section (just one question) was concerned with problems encountered by students during their use of these apps. The ninth section and the last one (just one question), which was an open-ended question, allowed students to add any comments and suggestions that they would like to mention in their questionnaire as well as opportunities to discuss issues that did not appear on the questionnaire. The questionnaire was completely anonymous. To introduce it, a cover letter accompanied the questionnaire. According to Linsky (1975), the questionnaire cover letter may help motivate respondents to reply to the questionnaire. All returned valid questionnaires were coded employing SPSS (version 17.0) spreadsheet.

\section{The population of the study}

The population of this study is undergraduate students enrolled in the year 2014/2015 at SVU's DLIS. Undergraduate students were defined in this study as those who were in one of the bachelor's grades: freshman, sophomore, junior and senior. In total, DLIS has 600 undergraduate students, of whom 523 as 
females and 77 as males. DLIS' faculty members are just one associate professor, three assistant professors, three teaching assistants and seven tutors. As much as possible, questionnaires were distributed to almost all students. Of the total number (600), 533 returned their valid questionnaires representing $88.83 \%$ of the total number of students.

Findings and analyses of the study

According to the order of the items listed in its questionnaire, the findings of this study are organized. They are also handled in terms of the answer of the eight research questions of the study. As appropriate, some items are cross-tabulated with each other. The sample of the study consisted of valid responses from 533 students representing the undergraduate students at SVU's DLIS. Of these 533 students, 441 students were using smart phones representing $82.7 \%$ of the total sample, and 92 students were not using them representing $17.3 \%$ of the total sample. Table 1 shows in details the features of both smart phone users and non-users.

Table 1.

Smart phone users' class standing is cross tabulated with their gender

\begin{tabular}{lllll}
\hline \multirow{2}{*}{$\begin{array}{l}\text { Class } \\
\text { standing }\end{array}$} & \multicolumn{2}{l}{ Smart phone users } & \multicolumn{2}{l}{ Smart phone non-users } \\
\cline { 2 - 5 } & Males & Females & Males & Females \\
\hline \multirow{3}{*}{ Freshman } & $\mathrm{N}^{*}$ & $\mathrm{~N}$ & $\mathrm{~N}$ & $\mathrm{~N}$ \\
\cline { 2 - 5 } Sophomore & $17 / 22$ & $68 / 117$ & $5 / 22$ & $13 / 117$ \\
Junior & $16 / 20$ & $115 / 163$ & $9 / 20$ & $38 / 163$ \\
Senior & $7 / 10$ & $140 / 153$ & $4 / 25$ & $16 / 153$ \\
\hline Total & $52 / 77$ & $66 / 90$ & $0 / 10$ & $7 / 90$ \\
& $(67.5 \%)$ & $(789 / 523$ & $18 / 77$ & $74 / 523$ \\
& $441 / 533=82.7 \%{ }^{* *}$ & $(23.4 \%)$ & $(14.1 \%)$ \\
\hline
\end{tabular}

* The selected sample/the total number of students at DLIS.

** The total number of smart phone users (males \& females)/the selected sample.

*** The total number of smart phone non-users (males \& females)/the selected sample.

RQ1. What are the demographic characteristics of smart phone users and non-users at SVU's DLIS? Of the 533 sampled students, there were 389 female students who were using smart phones representing $88.2 \%$ of the total sampled smart phone users and $84 \%$ of the sampled females $(74.4 \%$ of the female representation at DLIS). There were also 52 male students who were using these mobile devices representing $11.8 \%$ of the total sampled smart phone users and $74.3 \%$ of the sampled males $(67.5 \%$ of the male representation at DLIS) (Mean $=1.88 \& \mathrm{SD}=.323$ ). On the other hand, of the 533 surveyed students, 92 students were found to be smart phone non-users. Of these 92 students, 18 were males representing $19.6 \%$ of the total sampled smart phone non-users $(23.4 \%$ of the male representation at DLIS) and 74 females representing $80.4 \%$ of the total sampled smart phone non-users $(14.1 \%$ of the female representation at DLIS) (Mean $=1.80 \& \mathrm{SD}=.399$ ). Table III shows the mean and standard deviation of both smart phone users and non-users. Table II and III show the Mean and SD of both smart phone users and non-users. When students were asked to indicate their class standing (freshman, sophomore, junior and senior), of the 533 surveyed students, $102(19.1 \%)$ indicated that they were freshman or first year students, 178 (33.4) were sophomore or second year students, $173(32.5 \%)$ were junior or third year students and $80(15 \%)$ were senior or fourth year students. The study showed that 84 $(82.6 \%)$ of freshman students, $131(73.6 \%)$ of sophomore students, $153(88.4 \%)$ and $73(91.3 \%)$ were found to be smart phone users (Mean $=2.48 \& \mathrm{SD}=.984)$. The study also showed that the age of the surveyed students ranged from under 18 to 24 . Students who are aged less than 18 years were $32(6 \%)$, 
those aged between 19-20 years were 117 (21.6\%), those aged between 21-22 years were $325(60.8 \%)$ and those aged between $23-24$ years were $89(16.7 \%)$ students. The study showed that $20(62.5 \%)$ of students aged under 18 years, $66(56.4 \%)$ aged as 19-20, $272(83.7 \%)$ aged as 21-22 and $83(93.3 \%)$ aged as 23-24 years were found to be smart phone users $($ Mean $=2.95 \& \mathrm{SD}=.720)$.

Table II.

The demographic data of smart phone users and non-users at SVU's DLIS in details

\begin{tabular}{|c|c|c|c|c|}
\hline & \multicolumn{2}{|c|}{$\begin{array}{l}\text { Smart phone apps' } \\
\text { users }\end{array}$} & \multicolumn{2}{|c|}{$\begin{array}{l}\text { Smart phone apps' } \\
\text { non-users }\end{array}$} \\
\hline & Frequency & Percentage & Frequency & Percentage \\
\hline \multicolumn{5}{|l|}{ Gender } \\
\hline Male & 52 & 11.8 & 18 & 19.6 \\
\hline Female & 389 & 88.2 & 74 & 80.4 \\
\hline \multicolumn{5}{|l|}{ Age } \\
\hline-18 & 20 & 4.5 & 12 & 13 \\
\hline $19-20$ & 66 & 15 & 51 & 55.4 \\
\hline $21-22$ & 272 & 61.7 & 53 & 25 \\
\hline $23-24$ & 83 & 18.8 & 6 & 6.5 \\
\hline \multicolumn{5}{|l|}{$\begin{array}{l}\text { Class } \\
\text { standing }\end{array}$} \\
\hline Freshman & 84 & 19 & 18 & 19.6 \\
\hline Sophomore & 131 & 29.7 & 47 & 51.1 \\
\hline Junior & 153 & 34.7 & 20 & 21.7 \\
\hline Senior & 73 & 16.6 & 7 & 7.6 \\
\hline
\end{tabular}

Table III.

The demographic data of smart phone users and non-users According to the Mean and SD

\begin{tabular}{lllllll}
\hline & $\mathbf{N}$ & & Mean & & \multicolumn{2}{c}{ Std. Deviation } \\
\cline { 2 - 7 } & $\begin{array}{l}\text { Smart } \\
\text { phone }\end{array}$ & $\begin{array}{l}\text { Smart } \\
\text { phone } \\
\text { non-user }\end{array}$ & $\begin{array}{l}\text { Smart } \\
\text { phone } \\
\text { users }\end{array}$ & $\begin{array}{l}\text { Smart } \\
\text { phone } \\
\text { non-user }\end{array}$ & $\begin{array}{l}\text { Smart } \\
\text { phone }\end{array}$ & $\begin{array}{l}\text { Smart } \\
\text { phone }\end{array}$ \\
non-user \\
\hline $\begin{array}{l}\text { Participants' gender } \\
\text { Participants' } \\
\text { standing }\end{array}$ & 441 & 92 & 1.88 & 1.80 & .323 & .399 \\
Participants' age & 441 & 92 & 2.48 & 2.17 & .984 & .833 \\
\hline
\end{tabular}

Students who were described to be smart phone non-users were asked to report their level, among four scales given to them, of reasons of why they are not using smart phone apps. Students have given many varied answers ranging from "not significant" to "very significant". As shown in Table IV, findings revealed that $93.5 \%$ of students indicated that time to access apps was at least significant to them, followed by adequate funds $(81.5 \%)$, connection to the Internet $(77.2 \%)$, training about using apps (64.1\%), language \& technical skills (60.8\%), knowledge about apps (58.7\%), awareness about apps $(53.3 \%)$ and appropriate apps (29.3\%).

Table IV.

Barriers to NOT use smart phone apps by smart phone non-users

\begin{tabular}{lllll}
\hline Barriers to NOT use smart phone apps & $\begin{array}{l}\text { Very } \\
\text { significant }\end{array}$ & $\begin{array}{l}\text { Significa } \\
\text { nt }\end{array}$ & $\begin{array}{l}\text { Somewhat } \\
\text { significant }\end{array}$ & $\begin{array}{l}\text { Not } \\
\text { significant }\end{array}$ \\
\hline \hline
\end{tabular}




\begin{tabular}{|c|c|c|c|c|}
\hline & $(\%)$ & $(\%)$ & $(\%)$ & $(\%)$ \\
\hline $\begin{array}{l}\text { Lack of adequate funds needed to get } \\
\text { business apps }\end{array}$ & 34.8 & 46.7 & 18.5 & 0 \\
\hline Lack of time needed to access apps & 23.9 & 69.6 & 6.5 & 0 \\
\hline Lack of training to use different apps & 22.8 & 41.3 & 35.9 & 0 \\
\hline $\begin{array}{l}\text { Lack of the connection to the Internet needed } \\
\text { to access apps }\end{array}$ & 17.4 & 59.8 & 22.8 & 0 \\
\hline $\begin{array}{l}\text { Lack of language and technical skills needed } \\
\text { for some apps }\end{array}$ & 12 & 48.9 & 39.1 & 0 \\
\hline Lack of the awareness of apps & 5.4 & 47.8 & 46.7 & 0 \\
\hline Lack of the knowledge about apps & 4.3 & 54.3 & 41.3 & 0 \\
\hline Lack of appropriate apps & 4.3 & 25 & 67.4 & 3.3 \\
\hline
\end{tabular}

\section{The profile of smart phone users at SVU's DLIS}

RQ2. What are the features of the use of smart phones by students at SVU's DLIS (period of use, experience, first hearing about apps, location, the number of smart phones owned, smart phone brand and the number of apps accessed)?

As shown in Table V, findings showed that the highest percentage of smart phone users $(46 \%)$ indicated that they had been using these devices for 4 years to 5 years, followed by $24.9 \%$ using for more than six years, $21.8 \%$ using for 2 to 3 years and just $7.3 \%$ using for less than one year.

Table V.

The period of using apps by smart phone users through Mean, SE \& SD

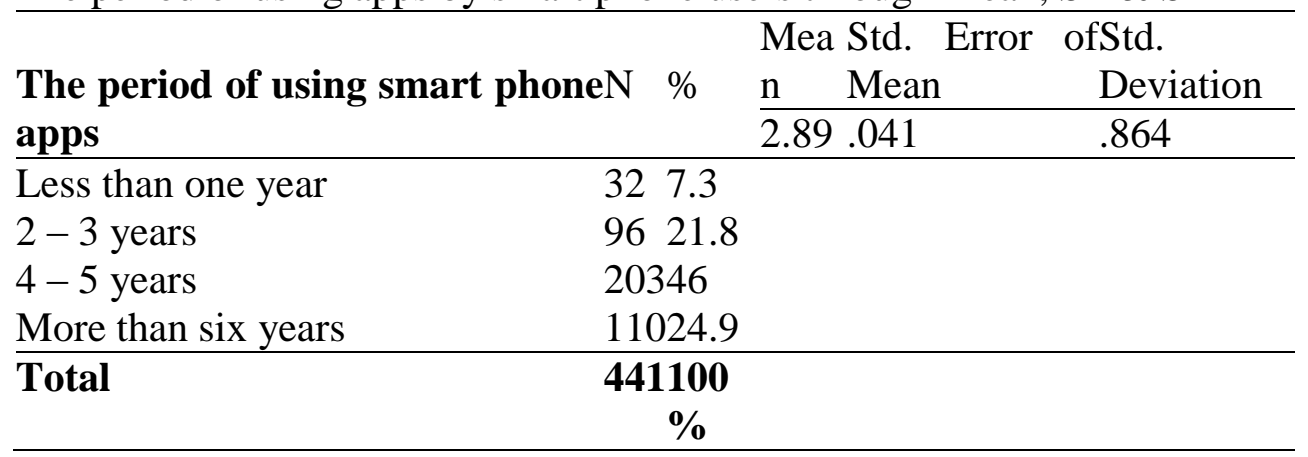

Findings showed that, as Table VI shows, the largest number of smart phone users surveyed in this study $(68 \%)$ was advanced users, followed by expert users $(16.1 \%)$, intermediate users $(13.6 \%)$ and novice users $(2.3 \%)$.

Table VI.

The expertise rate of using apps by smart phone users through Mean, SE \& SD

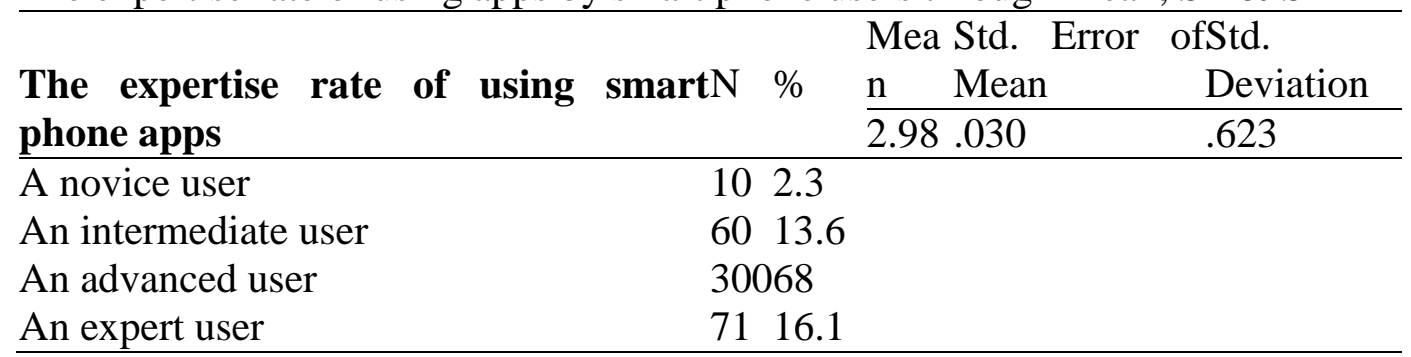




\begin{tabular}{cc}
\hline Total & 41100 \\
$\%$ \\
\hline
\end{tabular}

As shown in Table VII, this study found that the largest number of smart phone users (57.1\%) heard first about these devices through friends, followed by the Web (19.7\%), TV/Radio (10.2\%), magazines \& newspapers (4.8\%), professional journals (3.9\%), books (3.2\%) and Class (1.1\%).

\section{Table VII.}

The first hearing about apps by smart phone users through Mean, SE \& SD

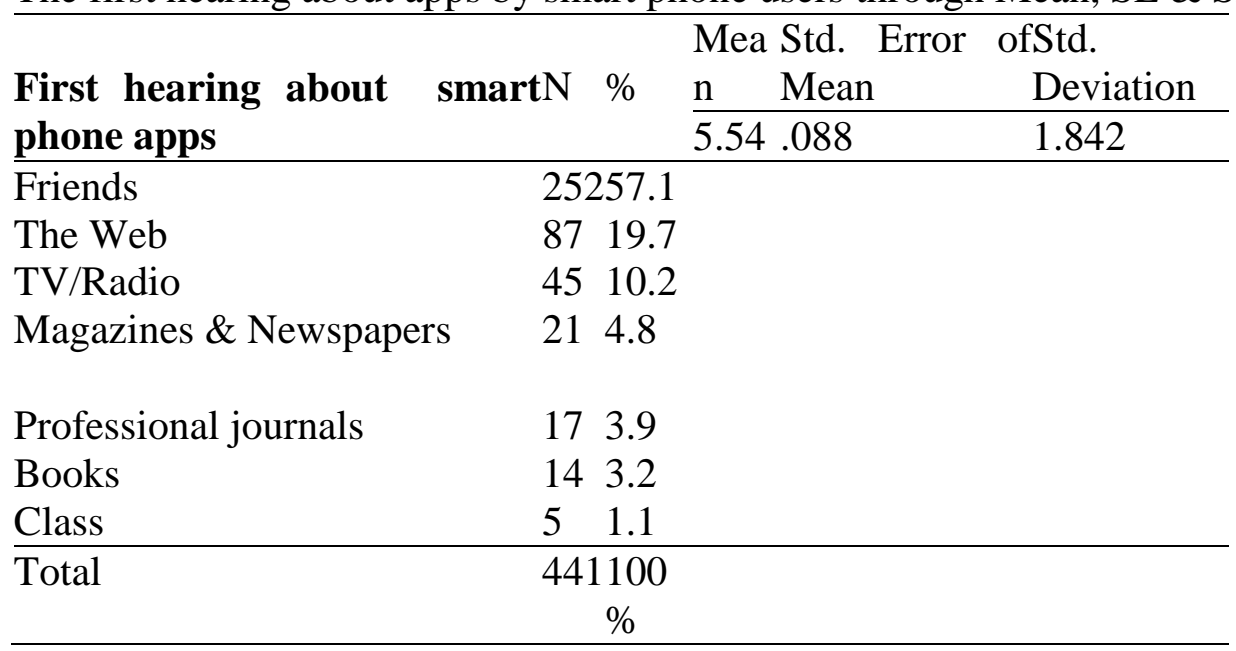

Students were asked to locate where they accessed smart phone apps. As Table VIII shows, findings showed that the most frequent location of students' access to these apps was from their home and university campus. In detail, $100 \%$ of smart phone users indicated that their access and use of these apps through their home/dormitory was at least high, followed by University campus (92.7\%), University library (73.2\%), and community centers (club, cyber, etc.) $(53.3 \%)$, class $(51.7 \%)$, public library $(42.8 \%)$ and work (19.9\%).

Table VIII.

Accessing apps by smart phone users

\begin{tabular}{llllll}
\hline $\begin{array}{l}\text { Accessing smart phone apps } \\
\text { through: }\end{array}$ & $\begin{array}{l}\text { Very } \\
\text { high } \\
(\%)\end{array}$ & $\begin{array}{l}\text { Hig } \\
\mathrm{h} \\
(\%)\end{array}$ & $\begin{array}{l}\text { Modera } \\
\text { te } \\
(\%)\end{array}$ & $\begin{array}{l}\text { Lo } \\
\mathrm{w} \\
(\%)\end{array}$ & $\begin{array}{l}\text { Very } \\
\text { low } \\
(\%)\end{array}$ \\
\hline $\begin{array}{l}\text { Home/Dormitory } \\
\text { University campus }\end{array}$ & 95.9 & 4.1 & 0 & 0 & 0 \\
$\begin{array}{l}\text { University library } \\
\text { Community center }\end{array}$ & 81 & 11.8 & 5.7 & 1.6 & 0 \\
$\begin{array}{l}\text { cybers, etc.) } \\
\text { Class }\end{array}$ & 37.4 & 35.8 & 30.6 & 5.7 & .5 \\
Public library & 27 & 26.3 & 34.2 & 12. & 0 \\
& & & & 5 & \\
Work & 23.1 & 28.6 & 39.2 & 40 & 0 \\
& 19.7 & 32.2 & 34.5 & 13. & 0 \\
& & & & 6 & \\
& 7.3 & 12.7 & 30.8 & 34. & 14.7 \\
\end{tabular}


Through One-Way ANOVA, the study revealed that there is no a statistically significant difference at the $p>.05$ level between the demographic characteristics (age, gender and class standing) of smart phone users and their location of using apps (Table IX).

Table IX.

Anova (shortened) by the location of accessing apps by students through Mean, SE \& SD

\begin{tabular}{|c|c|c|c|c|c|c|c|}
\hline & \multicolumn{4}{|c|}{ Statistics } & \multicolumn{3}{|c|}{ Level of Significance } \\
\hline $\begin{array}{l}\text { Accessing smart phone } \\
\text { apps from: }\end{array}$ & $\begin{array}{l}\mathrm{N} \\
(441)\end{array}$ & $\begin{array}{l}\text { Mea } \\
n\end{array}$ & $\begin{array}{l}\text { Std. } \\
\text { Error }\end{array}$ & SD & Age & $\begin{array}{l}\text { Gend } \\
\text { er }\end{array}$ & $\begin{array}{l}\text { Class } \\
\text { standing }\end{array}$ \\
\hline Home/Dormitory & & 4.96 & .009 & .198 & $\begin{array}{l}.49 \\
2\end{array}$ & .403 & .524 \\
\hline University campus & & 4.72 & .031 & .641 & $\begin{array}{l}.36 \\
5\end{array}$ & .909 & .391 \\
\hline University library & & 4.04 & .044 & .921 & $\begin{array}{l}.10 \\
8\end{array}$ & .888 & .124 \\
\hline $\begin{array}{l}\text { Community center (club, } \\
\text { cyber, etc.) }\end{array}$ & & 3.68 & .048 & $\begin{array}{l}1.00 \\
5\end{array}$ & $\begin{array}{l}.77 \\
7\end{array}$ & .359 & .880 \\
\hline Class & & 3.66 & .044 & .933 & $\begin{array}{l}.54 \\
2\end{array}$ & .899 & .662 \\
\hline Public library & & 3.58 & .045 & .955 & $\begin{array}{l}.23 \\
4\end{array}$ & .293 & .876 \\
\hline Work & & 2.63 & .053 & $\begin{array}{l}1.10 \\
4\end{array}$ & $\begin{array}{l}.92 \\
2\end{array}$ & .496 & .591 \\
\hline
\end{tabular}

As shown in Table $\mathrm{X}$, this study showed that a large number $(82.1 \%)$ of the students was having just one device, followed by two (16.8\%) and three and more $(1.1 \%)$.

Table X.

The number of smart phone devices owned by smart phone users through Mean, SE \& SD

\begin{tabular}{|c|c|c|c|}
\hline \multirow{3}{*}{$\begin{array}{l}\text { The number of smart phone devices ownedN } \\
\text { by students }\end{array}$} & \multirow{3}{*}{$\%$} & \multirow{3}{*}{\multicolumn{2}{|c|}{$\begin{array}{lll}\begin{array}{c}\text { Mean Std. Error } \\
\text { Mean }\end{array} & \begin{array}{c}\text { ofStd. } \\
\text { Deviation }\end{array} \\
1.19 \quad .020 & .421 \\
\end{array}$}} \\
\hline & & & \\
\hline & & & \\
\hline One & 36282.1 & & \\
\hline Two & 7416.8 & & \\
\hline Three and more & $5 \quad 1.1$ & & \\
\hline Total & $\begin{array}{c}441100 \\
\%\end{array}$ & & \\
\hline
\end{tabular}

This study also showed that the most predominant and popular brand smart phone users own was Android, followed by iPhone, Blackberry and Windows. In details, most of the smart phone users (72.3\%) own Android (Samsung \& Nokia), followed by Blackberry (12.9\%), iPhone (9.8\%) and Windows (5\%) (Table XI).

Table XI.

Smart phone brand owned by smart phone users through Mean, SE \& SD

\begin{tabular}{llllll}
\hline & & \multicolumn{2}{c}{ MeanStd. Error } & ofStd. \\
A smart phone brandN $\%$ & \multicolumn{2}{c}{ Mean } & Deviation \\
\cline { 3 - 5 } owned by users & & & 2.13 & .030 & .640 \\
\hline
\end{tabular}




\begin{tabular}{lcl}
\hline Android (Samsung \& Nokia) & 31972.3 \\
Blackberry & 57 & 12.9 \\
iPhone & 43 & 9.8 \\
Windows & 22 & 5 \\
\hline Total & $\mathbf{4 4 1 1 0 0}$ \\
& \multicolumn{9}{c}{} \\
\hline
\end{tabular}

As shown in Table XII, findings showed that the highest percentage of smart phone users (40.6\%) indicated that they have from 21 to 25 apps, followed by $28.6 \%$ having from 11 to 20 apps, $20.9 \%$ having from 26 to 30 apps, 8.2\% having from 6 to 10 apps, 2\% having more than 31 apps and just 1.6\% having from 1 to 5 apps.

Table XII.

The number of apps accessed by smart phone users through Mean, SE \& SD

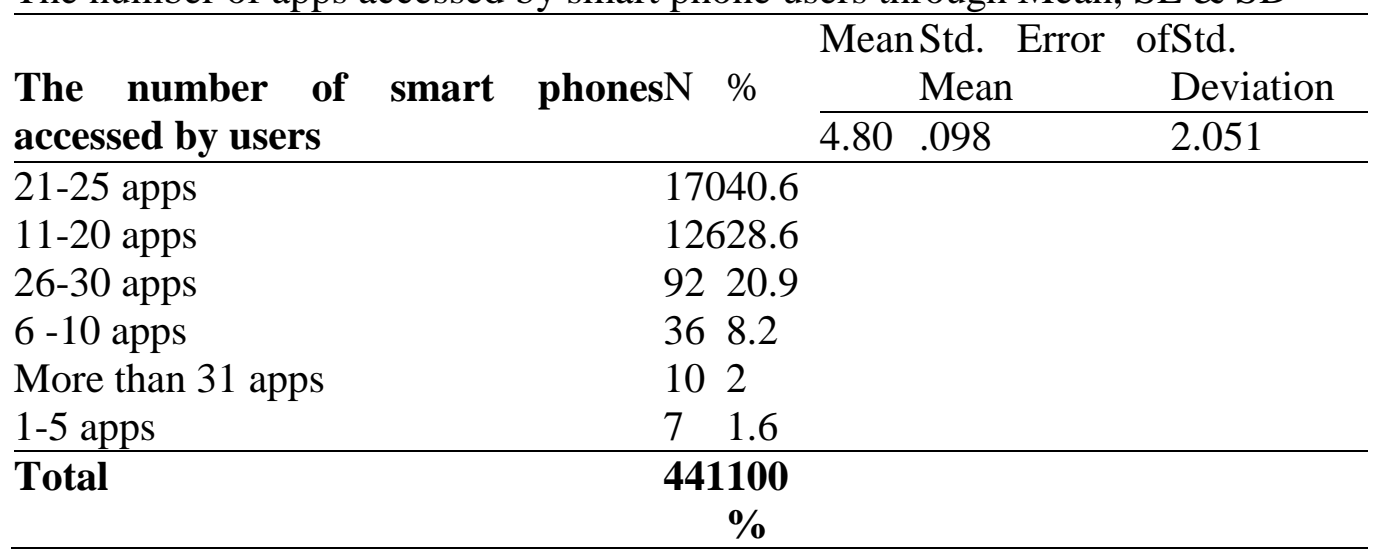

RQ3. Which types of apps do students at SVU's DLIS use most?

Among six scales given to them, smart phone users were asked to report the most types of apps they are using. Findings revealed that the most types of apps used by students, as Table XIII shows, was communication apps and messaging/texting/SMS. In detail, $100 \%$ of students indicated that "Communication apps" and "Messaging/Texting/SMS" are at least mostly used by them, followed by "Social networking sites apps" (87\%), "Entertainment apps" (80.3\%), "News apps" (62\%), "Games apps" (32.4\%), "Multimedia apps" (25.2\%), "Education apps" (23\%), "Health apps" (8.8\%) and "Business apps" $(6.6 \%)$.

Table XIII.

Types of apps by smart phone users

\begin{tabular}{|c|c|c|c|c|c|c|}
\hline Types of apps & $\begin{array}{l}\text { Completely } \\
\text { use } \\
(\%)\end{array}$ & $\begin{array}{l}\text { Mostly } \\
\text { use } \\
(\%)\end{array}$ & $\begin{array}{l}\text { Slightly } \\
\text { use } \\
(\%)\end{array}$ & $\begin{array}{l}\text { Slightly not } \\
\text { use } \\
(\%)\end{array}$ & $\begin{array}{l}\text { Mostly not } \\
\text { use } \\
\text { (\%) }\end{array}$ & $\begin{array}{l}\text { Completely } \\
\text { not use } \\
(\%)\end{array}$ \\
\hline Communication apps & 96.4 & 3.4 & 0 & 0 & 0 & 0 \\
\hline $\begin{array}{l}\text { Messaging/Texting/S } \\
\text { MS apps }\end{array}$ & 88.2 & 11.8 & 0 & 0 & 0 & 0 \\
\hline $\begin{array}{ll}\text { Social Networking } \\
\text { Sites apps }\end{array}$ & 48.8 & 38.3 & 10 & 2.9 & 0 & 0 \\
\hline Entertainment apps & 27 & 53.3 & 19 & .7 & 0 & 0 \\
\hline News apps & 11.1 & 51.2 & 31.3 & 6.3 & 0 & 0 \\
\hline Games apps & 5.9 & 26.5 & 32.4 & 24.9 & 8.8 & 1.4 \\
\hline Education apps & 3.4 & 20 & 48.8 & 21.1 & 6.6 & .2 \\
\hline
\end{tabular}




\begin{tabular}{lllllll}
\hline Health apps & 2.5 & 6.3 & 37.6 & 41 & 10.9 & 1.6 \\
Multimedia apps & 1.8 & 23.4 & 46.5 & 22.9 & 5.4 & 0 \\
Business apps & .5 & 13.4 & 46.9 & 32.7 & 6.1 & .5 \\
\hline
\end{tabular}

Through One-Way ANOVA, the study revealed that there is a statistically significant difference at the $p$ $>.05$ level between the age of students and their use types of apps, such as social networking sites apps ( $p$ $=.002)$, entertainment apps $(p=.029)$, multimedia apps $(p=.000)$, education apps $(p=.000)$, games apps $(p=.000)$, health apps $(p=.030)$ and business apps $(p=.029)$. The study also revealed that there is a statistically significant difference between the students' gender and their use types of apps, such as multimedia apps $(p=.049)$ and education apps $(p=.005)$ and as well as their class standing and their use types of apps, such as communication apps $(p=.005)$, social networking sites $(p=.000)$, news apps $(p=.007 \%)$, multimedia apps $(p=.000)$, education apps $(p=.000)$, games apps $(p=.000)$ and business apps $(p=.000)$ (Table XIV).

Table XIV.

ANOVA (shortened) by types of smart phone apps used by students and their demography through Mean, SE \& SD

\begin{tabular}{|c|c|c|c|c|c|c|c|}
\hline \multirow[b]{2}{*}{$\begin{array}{l}\text { Types of smart phone apps } \\
\text { mostly used }\end{array}$} & \multicolumn{4}{|c|}{ Statistics } & \multicolumn{3}{|c|}{ Level of Significance } \\
\hline & $\mathrm{N}$ & $\begin{array}{l}\text { Mea } \\
\mathrm{n}\end{array}$ & $\begin{array}{l}\text { Std. } \\
\text { Error }\end{array}$ & SD & Age & $\begin{array}{l}\text { Gend } \\
\text { er }\end{array}$ & $\begin{array}{l}\text { Class } \\
\text { standing }\end{array}$ \\
\hline Communication apps & 441 & 5.97 & .009 & .181 & $\begin{array}{l}.18 \\
4\end{array}$ & .851 & .005 \\
\hline Messaging/Texting/SMS apps & 441 & 5.88 & .015 & .323 & $\begin{array}{l}.95 \\
6\end{array}$ & .393 & .471 \\
\hline Social Networking Sites apps & 441 & 5.33 & .037 & .774 & $\begin{array}{l}.00 \\
2\end{array}$ & .985 & .000 \\
\hline Entertainment apps & 441 & 5.07 & .033 & .696 & $\begin{array}{l}.02 \\
9\end{array}$ & .069 & .050 \\
\hline News apps & 441 & 4.67 & .036 & .756 & $\begin{array}{l}.50 \\
5\end{array}$ & .053 & .007 \\
\hline Multimedia apps & 441 & 3.93 & .041 & .866 & $\begin{array}{l}.00 \\
0\end{array}$ & .049 & .000 \\
\hline Education apps & 441 & 3.92 & .043 & .908 & $\begin{array}{l}.00 \\
0\end{array}$ & .005 & .000 \\
\hline Games apps & 441 & 3.92 & .053 & $\begin{array}{l}1.10 \\
6\end{array}$ & $\begin{array}{l}.00 \\
0\end{array}$ & .932 & .000 \\
\hline Health apps & 441 & 3.44 & .044 & .915 & $\begin{array}{l}.03 \\
0\end{array}$ & .158 & .183 \\
\hline Business apps & 441 & 3.32 & .039 & .815 & $\begin{array}{l}.02 \\
9\end{array}$ & .230 & .000 \\
\hline
\end{tabular}

Students using smart phones were asked how many hours a day they spent using these apps. They were given four options: 1 = one hour or less, $2=2-3$ hours, $3=4-5$ hours, $4=6$ hours or more from which to choose only one. Findings showed that a large number of the students $(85 \%)$ spend six hours and more on using these apps, followed by $13.4 \%$ spending between 4 to 5 hours a day and just $1.6 \%$ who spend between 2 to 3 hours a day.

Among six scales given to them, smart phone users were also asked to report the most apps they were using. Findings revealed that the most apps mostly used and accessed by students, as Table XV shows, were Facebook, E-mail, Twitter, What's app and Youtube. In detail, 100\% of students indicated that 
Facebook, followed by E-mail (98.6\%), Twitter (96.1\%), What's app (94.6\%), Youtube (93.7\%), Viber (67.4\%), Kik (66.9\%), Line (61.5\%), Skype (61.4\%), Tango (60.3\%), Google mobile (44.7\%), Wikipedia mobile (21.3\%), Instgram (11.5\%), Google maps $(11.1 \%$,) and Flickr $(9.5 \%)$ were at least mostly used by them.

\section{Table XV.}

The most apps used and accessed by smart phone users

\begin{tabular}{|c|c|c|c|c|c|c|}
\hline $\begin{array}{l}\text { Smart phone apps } \\
\text { mostly accessed by } \\
\text { students }\end{array}$ & $\begin{array}{l}\text { Completely } \\
\text { use } \\
(\%)\end{array}$ & $\begin{array}{l}\text { Mostly } \\
\text { use } \\
(\%)\end{array}$ & $\begin{array}{l}\text { Slightly } \\
\text { use } \\
(\%)\end{array}$ & $\begin{array}{l}\text { Slightly not } \\
\text { use } \\
(\%)\end{array}$ & $\begin{array}{l}\text { Mostly not } \\
\text { use } \\
(\%)\end{array}$ & $\begin{array}{l}\text { Completely } \\
\text { not use } \\
(\%)\end{array}$ \\
\hline E-mail app & 84.1 & 14.5 & 1.4 & 0 & 0 & 0 \\
\hline Facebook & 79.1 & 20.9 & 0 & 0 & 0 & 0 \\
\hline Twitter & 69.6 & 26.5 & 2.7 & .9 & .2 & 0 \\
\hline Youtube & 67.6 & 26.1 & 4.5 & 1.6 & .2 & 0 \\
\hline What's app. & 65.8 & 28.8 & 4.3 & .9 & .2 & 0 \\
\hline Kik & 22.7 & 44.2 & 28.6 & 4.5 & 0 & 0 \\
\hline Viber & 22 & 45.4 & 30.4 & 2.3 & 0 & 0 \\
\hline Line & 16.8 & 44.7 & 33.3 & 5.2 & 0 & 0 \\
\hline Skype & 16.3 & 45.1 & 34 & 4.5 & 0 & 0 \\
\hline Tango & 16.1 & 44.2 & 34.7 & 5 & 0 & 0 \\
\hline Google mobile & 7.9 & 36.8 & 21.4 & 22.8 & 9.5 & 1.1 \\
\hline Wikipedia mobile & 2 & 19.3 & 62.4 & 15.2 & .7 & .5 \\
\hline Instagram & 2 & 9.5 & 24.5 & 37.6 & 20.2 & 6.1 \\
\hline Google maps & 2 & 9.1 & 24.3 & 38.1 & 20.4 & 6.1 \\
\hline Flickr & 1.8 & 7.7 & 25.2 & 38.5 & 20.6 & 6.1 \\
\hline
\end{tabular}

Through One-Way ANOVA, the study revealed that there is a statistically significant difference at the $p$ $>.05$ level between the age of students and apps that are mostly accessed by them, such as Facebook $(p=$ $.044)$, Viber $(p=.000)$, Kik $(p=.000)$, Instgram $(p=.002)$, Google maps $(p=.005)$ and Flickr $(p=.002)$. The study also revealed that there is a statistically significant difference between the students' gender and apps that are mostly accessed by them, such as Viber $(p=.011)$ and Kik $(p=.006)$ as well as their class standing and apps that are mostly accessed by them, such as E-mail $(p=.000)$, Facebook $(p=.001)$, Viber $(p=.000)$, Kik $(p=.000)$, Instgram $(p=.000)$, Google maps $(p=.000)$ and Flickr $(p=.000)$ (Table $\mathrm{XVI})$.

Table XVI.

ANOVA (shortened) by smart phone apps mostly accessed by students and their demography through Mean, SE \& SD

\begin{tabular}{lllllll}
\hline $\begin{array}{l}\text { Smart phone apps } \\
\text { mostly accessed } \\
\text { students }\end{array}$ & \multicolumn{3}{l}{ Statistics } & \multicolumn{4}{c}{ Level of Significance } \\
\cline { 2 - 7 } & $\begin{array}{l}\text { Mea } \\
\mathrm{n}\end{array}$ & SE & SD & & $\begin{array}{l}\text { Gend } \\
\text { er }\end{array}$ & $\begin{array}{l}\text { Class } \\
\text { standing }\end{array}$ \\
\hline E-mail app & 5.83 & .02 & .413 & .09 & .277 & .000 \\
& & 0 & & 5 & & \\
Face book & 5.79 & .01 & .407 & .04 & .132 & .001 \\
& & 9 & & 4 & & \\
Twitter & 5.64 & .02 & .605 & .31 & .901 & .742 \\
& & 9 & & 8 & & \\
Youtube & 5.59 & .03 & .675 & .41 & .698 & .540 \\
\hline
\end{tabular}




\begin{tabular}{|c|c|c|c|c|c|c|}
\hline & & 2 & & 7 & & \\
\hline What's app. & 5.59 & $\begin{array}{l}.03 \\
1\end{array}$ & .641 & $\begin{array}{l}.48 \\
6\end{array}$ & .703 & .917 \\
\hline Viber & 4.87 & $\begin{array}{l}.03 \\
7\end{array}$ & .774 & $\begin{array}{l}.00 \\
0\end{array}$ & .011 & .000 \\
\hline Kik & 4.85 & $\begin{array}{l}.03 \\
9\end{array}$ & .820 & $\begin{array}{l}.00 \\
0\end{array}$ & .006 & .000 \\
\hline Line & 4.73 & $\begin{array}{l}.03 \\
8\end{array}$ & .799 & $\begin{array}{l}.51 \\
5\end{array}$ & .141 & .857 \\
\hline Skype & 4.73 & $\begin{array}{l}.03 \\
7\end{array}$ & .784 & $\begin{array}{l}.38 \\
6\end{array}$ & .442 & .158 \\
\hline Tango & 4.71 & $\begin{array}{l}.03 \\
8\end{array}$ & .792 & $\begin{array}{l}.50 \\
1\end{array}$ & .275 & .259 \\
\hline Google mobile & 4.07 & 056 & $\begin{array}{l}1.18 \\
2\end{array}$ & $\begin{array}{l}.64 \\
8\end{array}$ & .102 & .092 \\
\hline Wikipedia mobile & 4.05 & $\begin{array}{l}.03 \\
3\end{array}$ & .702 & $\begin{array}{l}.79 \\
4\end{array}$ & .086 & .079 \\
\hline Instagram & 3.17 & $\begin{array}{l}.05 \\
3\end{array}$ & $\begin{array}{l}1.10 \\
9\end{array}$ & $\begin{array}{l}.00 \\
2\end{array}$ & .185 & .000 \\
\hline Google maps & 3.16 & $\begin{array}{l}.05 \\
3\end{array}$ & $\begin{array}{l}1.10 \\
3\end{array}$ & $\begin{array}{l}.00 \\
5\end{array}$ & .332 & .000 \\
\hline Flickr & 3.13 & $\begin{array}{l}.05 \\
1\end{array}$ & $\begin{array}{l}1.07 \\
7\end{array}$ & $\begin{array}{l}.00 \\
2\end{array}$ & .349 & .000 \\
\hline
\end{tabular}

\section{RQ4. Which apps do students at SVU's DLIS use for education and library-related activities?}

Findings revealed that some smart phone users were using some apps for professional purposes and library-related activities, such as Google mobile, Facebook, E-mail, Twitter, Youtube, What's app, Wikipedia mobile and Instgram. In detail, when all smart phone users were asked to indicate if they use any apps related to education and library-related activities or not, they reported that they were using some apps, such as Google mobile (81.4\%), Facebook (78.9\%), E-mail (71\%), Twitter (67\%), Youtube (61\%), Wikipedia mobile (49.2\%) and Instgram (34\%).

RQ5. What are the characteristics (ease and usefulness of use) of the apps' use by students at SVU's DLIS?

Students were asked to indicate their level of the ease of the use of smart phone apps. Respectively, findings revealed that E-mail, Google mobile, Facebook, What's app, Kik, Twitter, Youtube were the most easiest apps indicated by students. In detail, $100 \%$ of students indicated that the use of E-mail app was at least fairly easy to them, followed by Google mobile (95.9\%), Facebook app (95.7\%), what's app (93.9\% ), Kik (93.7\%), Twitter (93.2\%), Youtube (93.2\%), Google maps (92.8\%), Viber (92.5\%), Line (92.3\%), Skype (92.3\%), Tango (92.1\%) Instgram (91.4\%), Flickr (90.7\%) and Wikipedia mobile $(90.1 \%)$ (Table XVII).

Table XVII.

The ease of the use of smart phone apps by students

\begin{tabular}{lllllll}
\hline $\begin{array}{l}\text { Ease of use of } \\
\text { phone apps }\end{array}$ & smart & $\begin{array}{l}\text { Extremely } \\
\text { easy } \\
(\%)\end{array}$ & $\begin{array}{l}\text { Fairly } \\
\text { easy } \\
(\%)\end{array}$ & $\begin{array}{l}\text { No strong } \\
\text { opinion } \\
(\%)\end{array}$ & $\begin{array}{l}\text { Not at all } \\
\text { easy } \\
(\%)\end{array}$ & $\begin{array}{l}\text { Have never } \\
\text { used } \\
(\%)\end{array}$ \\
\hline E-mail app & 80.5 & 19.5 & $\mathbf{0}$ & 0 & 0 \\
\hline
\end{tabular}




\begin{tabular}{llllll}
\hline Facebook & 65.3 & 30.2 & 4.5 & 0 & 0 \\
Twitter & 63.5 & 30.2 & 4.8 & .7 & .9 \\
Skype & 44 & 48.3 & 7.7 & 0 & 0 \\
Line & 43.8 & 48.5 & 7.7 & 0 & 0 \\
What's app. & 42.2 & 51.7 & 6.1 & 0 & 0 \\
Tango & 42.2 & 49.9 & 7.9 & 0 & 0 \\
Youtube & 40.1 & 53.1 & 6.8 & 0 & 0 \\
Viber & 39.9 & 52.6 & 7 & 0 & .5 \\
Flickr & 34 & 56.7 & 7.9 & .9 & .5 \\
Google maps & 28.8 & 64.2 & 6.1 & .2 & .5 \\
Google mobile & 21.1 & 75.1 & 3.9 & 0 & 0 \\
Wikipedia mobile & 19.5 & 70.5 & 8.8 & .7 & .5 \\
Instagram & 17 & 74.6 & 2.5 & 2 & 3.9 \\
Kik & 15.6 & 42 & 27.7 & 10.2 & 4.5 \\
\hline
\end{tabular}

Students using apps were also asked to indicate their level of the usefulness of apps they are using. Findings revealed, as Table XVIII shows, that E-mail, Google mobile, What's app, Facebook, Youtube, Twitter and Viber respectively are the most useful apps indicated by students. In deltas, $100 \%$ of students indicated that the use of this E-mail app was "at least" fairly useful to them, followed by Google mobile (99.3\%), what's app (99.1\%), Facebook (98.9\%), Youtube (98.9\%), Twitter (98.7\%), Viber (97.1\%), Instgram (95.1\%), Wikipedia mobile (94.3\%), Google maps (94.1\%), Kik (93.4\%), Skype (93.2\%), Line (91.9\%), Tango $(89.8 \%)$ and Flickr $(85.9 \%)$.

Table XVIII.

The usefulness of the use of apps by smart phone users

\begin{tabular}{|c|c|c|c|c|c|}
\hline $\begin{array}{l}\text { The usefulness of smart } \\
\text { phone apps }\end{array}$ & $\begin{array}{l}\text { Extremely } \\
\text { useful } \\
(\%)\end{array}$ & $\begin{array}{l}\text { Fairly } \\
\text { useful } \\
(\%)\end{array}$ & $\begin{array}{l}\text { No strong } \\
\text { opinion } \\
(\%)\end{array}$ & $\begin{array}{l}\text { Not at all } \\
\text { useful } \\
(\%)\end{array}$ & $\begin{array}{l}\text { Have never } \\
\text { used } \\
(\%)\end{array}$ \\
\hline Youtube & 81.2 & 17.7 & 1.1 & 0 & 0 \\
\hline Twitter & 78.2 & 20.6 & 1.1 & 0 & 0 \\
\hline What's app & 77.1 & 21.8 & 1.1 & 0 & 0 \\
\hline Facebook & 68.9 & 29.9 & 1.1 & 0 & 0 \\
\hline Google mobile & 68.5 & 30.8 & .7 & 0 & 0 \\
\hline Viber & 67.3 & 29.9 & 2.7 & 0 & 0 \\
\hline E-mail & 66 & 34 & 0 & 0 & 0 \\
\hline Instagram & 63.3 & 31.7 & 3.9 & .2 & .9 \\
\hline Kik & 63 & 30.4 & 5.4 & .2 & .9 \\
\hline Google maps & 62.6 & 31.5 & 5.7 & .2 & 0 \\
\hline Skype & 43.3 & 49.9 & 6.8 & 0 & 0 \\
\hline Line & 42.6 & 49.4 & 7.9 & 0 & 0 \\
\hline Tango & 42.2 & 47.6 & 10.2 & 0 & 0 \\
\hline Wikipedia mobile & 28.1 & 66.4 & 5.4 & 0 & 0 \\
\hline Flickr & 21.8 & 64.2 & 12 & 2 & 0 \\
\hline
\end{tabular}

Through One-Way ANOVA, the study revealed that there is a statistically significant difference at the $p$ $>.05$ level between the age of students and the ease of apps' use, such as Youtube $(p=.008)$, Flickr $(p=$ $.000)$, Google mobile $(p=.009)$, Google maps $(p=.000)$, Instgram $(p=.030)$ and Kik $(p=.012)$. There is also a statistically significant difference between the students' gender and the ease of their use of apps, such as Facebook $(p=.031)$ as well as their class standing and Facebook $(p=.015)$, What's app $(p=$ 
$.000)$, Youtube $(p=.000)$, Viber $(p=.000)$, Flickr $(p=.000)$, Google mobile $(p=.000)$, Google maps $(p$ $=.000)$, Instgram $(p=.001)$ and Kik $(p=.000)$. The study also revealed that there is a statistically significant difference at the $p>.05$ level between the students' gender and the usefulness of the apps' use, such as Facebook $(p=.043)$ and Viber $(p=.040)$ as well as their class standing and E-mail $(p=.008)$, Facebook $(p=.024)$, Twiter $(p=.005)$, What's app $(p=.007)$, Viber $(p=.004)$ and Google mobile $(p=$ .042) (Table XIX).

Table XIX.

ANOVA (shortened) by Ease \& usefulness of using apps and students' demography through Mean, SE \& SD

\begin{tabular}{|c|c|c|c|c|c|c|c|c|c|c|c|c|}
\hline \multirow{3}{*}{$\begin{array}{l}\text { Ease } \\
\text { usefulness } \\
\text { of using apps }\end{array}$} & \multicolumn{6}{|c|}{ Ease of using apps } & \multicolumn{6}{|c|}{ The usefulness of using apps } \\
\hline & \multicolumn{3}{|c|}{ Statistics } & \multicolumn{3}{|c|}{ Level of Significance } & \multicolumn{2}{|c|}{ Statistics } & & \multicolumn{3}{|c|}{ Level of Significance } \\
\hline & $\begin{array}{l}\text { Mea } \\
n\end{array}$ & SE & SD & Age & $\begin{array}{l}\text { Gend } \\
\text { er }\end{array}$ & $\begin{array}{l}\text { Class } \\
\text { standin } \\
\mathrm{g}\end{array}$ & $\begin{array}{l}\text { Mea } \\
n\end{array}$ & SE & SD & Age & $\begin{array}{l}\text { Gend } \\
\text { er }\end{array}$ & $\begin{array}{l}\text { Class } \\
\text { standin } \\
\mathrm{g}\end{array}$ \\
\hline E-mail app & 4.80 & $\begin{array}{l}.01 \\
9\end{array}$ & .397 & $\begin{array}{l}.83 \\
4\end{array}$ & .672 & .101 & 4.66 & $\begin{array}{l}.02 \\
3\end{array}$ & $\begin{array}{l}.47 \\
4\end{array}$ & $\begin{array}{l}.10 \\
9\end{array}$ & .077 & .008 \\
\hline Facebook & 4.61 & $\begin{array}{l}.02 \\
7\end{array}$ & .574 & $\begin{array}{l}.18 \\
2\end{array}$ & .031 & .015 & 4.68 & $\begin{array}{l}.02 \\
3\end{array}$ & $\begin{array}{l}.49 \\
1\end{array}$ & $\begin{array}{l}.41 \\
5\end{array}$ & .043 & .024 \\
\hline Twitter & 4.55 & $\begin{array}{l}.03 \\
3\end{array}$ & .703 & $\begin{array}{l}.32 \\
9\end{array}$ & .452 & .460 & 4.77 & $\begin{array}{l}.02 \\
1\end{array}$ & $\begin{array}{l}.47 \\
7\end{array}$ & $\begin{array}{l}.91 \\
1\end{array}$ & .105 & .005 \\
\hline What's app. & 4.36 & $\begin{array}{l}.02 \\
8\end{array}$ & .595 & $\begin{array}{l}.06 \\
5\end{array}$ & .496 & .000 & 4.76 & $\begin{array}{l}.02 \\
2\end{array}$ & $\begin{array}{l}.45 \\
4\end{array}$ & $\begin{array}{l}.75 \\
5\end{array}$ & .143 & .007 \\
\hline Line & 4.36 & $\begin{array}{l}.03 \\
0\end{array}$ & .621 & $\begin{array}{l}.94 \\
3\end{array}$ & .514 & .797 & 4.35 & $\begin{array}{l}.03 \\
0\end{array}$ & $\begin{array}{l}.62 \\
1\end{array}$ & $\begin{array}{l}.84 \\
1\end{array}$ & .059 & .250 \\
\hline Skype & 4.36 & $\begin{array}{l}.03 \\
0\end{array}$ & .621 & $\begin{array}{l}.16 \\
7\end{array}$ & .788 & .125 & 4.37 & $\begin{array}{l}.02 \\
9\end{array}$ & $\begin{array}{l}.60 \\
7\end{array}$ & $\begin{array}{l}.45 \\
3\end{array}$ & .329 & .886 \\
\hline Tango & 4.34 & $\begin{array}{l}.03 \\
0\end{array}$ & .620 & $\begin{array}{l}.10 \\
7\end{array}$ & .366 & .095 & 4.32 & $\begin{array}{l}.03 \\
1\end{array}$ & $\begin{array}{l}.65 \\
0\end{array}$ & $\begin{array}{l}.51 \\
6\end{array}$ & .712 & .906 \\
\hline Youtube & 4.33 & $\begin{array}{l}.02 \\
9\end{array}$ & .599 & $\begin{array}{l}.00 \\
8\end{array}$ & .412 & .000 & .480 & $\begin{array}{l}.02 \\
0\end{array}$ & $\begin{array}{l}.42 \\
8\end{array}$ & $\begin{array}{l}.91 \\
1\end{array}$ & .131 & .828 \\
\hline Viber & 4.32 & $\begin{array}{l}.03 \\
1\end{array}$ & .642 & $\begin{array}{l}.29 \\
0\end{array}$ & .436 & .000 & 4.65 & $\begin{array}{l}.02 \\
5\end{array}$ & $\begin{array}{l}.53 \\
3\end{array}$ & $\begin{array}{l}.17 \\
3\end{array}$ & .040 & .004 \\
\hline Flickr & 4.23 & $\begin{array}{l}.03 \\
2\end{array}$ & .667 & $\begin{array}{l}.00 \\
0\end{array}$ & .495 & .000 & 4.06 & $\begin{array}{l}.03 \\
1\end{array}$ & $\begin{array}{l}.64 \\
6\end{array}$ & $\begin{array}{l}.86 \\
0\end{array}$ & .249 & .999 \\
\hline Google maps & 4.21 & $\begin{array}{l}.02 \\
8\end{array}$ & .598 & $\begin{array}{l}.00 \\
0\end{array}$ & .830 & .000 & 4.56 & $\begin{array}{l}.02 \\
9\end{array}$ & $\begin{array}{l}.61 \\
1\end{array}$ & $\begin{array}{l}.36 \\
5\end{array}$ & .263 & .408 \\
\hline Google mobile & 4.17 & $\begin{array}{l}.02 \\
2\end{array}$ & .469 & $\begin{array}{l}.00 \\
9\end{array}$ & .763 & .000 & $\begin{array}{l}4.06 \\
8\end{array}$ & $\begin{array}{l}.02 \\
3\end{array}$ & $\begin{array}{l}.48 \\
2\end{array}$ & $\begin{array}{l}.52 \\
4\end{array}$ & .252 & .042 \\
\hline $\begin{array}{l}\text { Wikipedia } \\
\text { mobile }\end{array}$ & 4.08 & $\begin{array}{l}.02 \\
8\end{array}$ & .588 & $\begin{array}{l}.63 \\
7\end{array}$ & .331 & .101 & 4.23 & $\begin{array}{l}.02 \\
5\end{array}$ & $\begin{array}{l}.53 \\
4\end{array}$ & $\begin{array}{l}.50 \\
1\end{array}$ & .954 & .530 \\
\hline Instagram & 3.99 & $\begin{array}{l}.03 \\
8\end{array}$ & .790 & $\begin{array}{l}.03 \\
0\end{array}$ & .939 & .001 & 4.56 & $\begin{array}{l}.03 \\
2\end{array}$ & $\begin{array}{l}.66 \\
8\end{array}$ & $\begin{array}{l}.36 \\
5\end{array}$ & .543 & .525 \\
\hline Kik & 3.54 & $\begin{array}{l}.04 \\
9 \\
\end{array}$ & $\begin{array}{l}1.02 \\
0 \\
\end{array}$ & $\begin{array}{l}.01 \\
2 \\
\end{array}$ & .081 & .000 & 4.54 & $\begin{array}{l}.03 \\
3 \\
\end{array}$ & $\begin{array}{l}.69 \\
3 \\
\end{array}$ & $\begin{array}{l}.38 \\
8 \\
\end{array}$ & .431 & .670 \\
\hline
\end{tabular}

RQ6. Which tasks do students at SVU's DLIS on smart phone apps? 
Students were asked to report their level of the importance of the tasks done on apps. As shown in Table XX., findings revealed that the highest level of importance was "sending and receiving messages" and "following the news". In detail, 100 of students indicate that "Sending and receiving messages" and "Following the news" are at least important to them, followed by "Making communications (99.5\%), "Making chat" (99.4\%), "Making friends" (99.3\%), "Finding specific information" (97.7\%), "Finding general information" (97.7\%), "Making discussion groups" (97.5\%), "Wasting time" (78.4\%), "Playing games" (73.4\%), "Completing class assignments" (62.3\%), "Checking materials related to courses" (58.7\%), "Doing business" (56\%), "Seeking jobs" (54.4\%), "Watching movies" (39.2\%), "Listening to music" (15.9\%), "Accessing library services" (6.6\%) and "Dating someone" (1.6\%).

\section{Table XX.}

Tasks done on apps by smart phone users

\begin{tabular}{lllll}
\hline Tasks done on smart phone apps & $\begin{array}{l}\text { Very } \\
\text { important } \\
(\%)\end{array}$ & $\begin{array}{l}\text { Importa } \\
\text { nt } \\
(\%)\end{array}$ & $\begin{array}{l}\text { Somewhat } \\
\text { important } \\
(\%)\end{array}$ & $\begin{array}{l}\text { Not } \\
\text { important } \\
(\%)\end{array}$ \\
\hline Sending and receiving messages & 94.6 & 5.4 & 0 & 0 \\
Following the news & 82.3 & 17.7 & 0 & 0 \\
Finding general information & 74.1 & 23.6 & 2.3 & 0 \\
Finding specific information related & 70.7 & 27 & 2.3 & 0 \\
to courses & & & & \\
Making friends & 63 & 36.3 & .7 & 0 \\
Making a chat & 63 & 36.3 & .7 & 0 \\
Making communications & 61.9 & 37.6 & .5 & 0 \\
Making discussion groups & 58.5 & 39 & 2.5 & 0 \\
Wasting time & 44.7 & 33.6 & 15.6 & 5.9 \\
Playing games & 34.7 & 38.5 & 21.1 & 5.4 \\
Watching movies/videos & 16.3 & 22.9 & 36.3 & 24.5 \\
Checking materials related to courses, & 5.4 & 53.3 & 40.1 & 1.1 \\
grades, etc. & & & & 35.8 \\
Listening to music & 5.2 & 10.7 & 48.3 & 0 \\
Completing class assignments & 5 & 57.4 & 37.6 & .9 \\
Doing business & 5 & 51 & 43.1 & 1.6 \\
Seeking jobs & 4.1 & 50.3 & 44 & 47.2 \\
Accessing library services & .9 & 5.7 & 46.3 & 66.2 \\
Dating someone & .2 & 1.4 & 32.2 & \\
\hline
\end{tabular}

Through One-Way ANOVA, the study revealed that there is a statistically significant difference at the $p>.05$ level between the age of students and tasks done on apps, such as finding general information $(p=$ $.005)$, finding specific information $(p=.011)$, watching movies $(p=.004)$, listening to music $(p=.039)$ and accessing library services $(p=.006)$. There is also a statistically significant difference between the students' gender and tasks done on apps, such as completing class assignments $(p=.019)$, checking materials related to courses $(p=.045)$, seeking jobs $(p=.020)$ and dating someone $(p=.001)$. The study also found that there is a statistically significant difference between the students' class standing and their tasks done on apps, such as finding general information $(p=.000)$, finding specific information $(p=$ $.000)$, making discussion groups $(p=.035)$, wasting time $(p=.000)$ and playing games $(p=.000)$, seeking jobs $(p=.021)$, dating someone $(p=.008)$, wasting time $(p=.000)$, playing games $(p=.000)$, watching movies $(p=.000)$, listening to music $(p=.000)$ and accessing library services $(p=.001)$ (Table $\mathrm{XXI})$. 
Table XXI.

ANOVA (shortened) by tasks done on apps and students' demography through Mean, SE \& SD

\begin{tabular}{|c|c|c|c|c|c|c|c|}
\hline \multirow[b]{2}{*}{ Tasks done on smart phone apps } & \multicolumn{4}{|c|}{ Statistics } & \multicolumn{3}{|c|}{ Level of Significance } \\
\hline & $\begin{array}{l}\mathrm{N} \\
(441)\end{array}$ & $\begin{array}{l}\text { Mea } \\
\mathrm{n}\end{array}$ & SE & SD & Age & $\begin{array}{l}\text { Gend } \\
\text { er }\end{array}$ & $\begin{array}{l}\text { Class } \\
\text { standing }\end{array}$ \\
\hline Sending and receiving messages & & 3.95 & $\begin{array}{l}.01 \\
1\end{array}$ & .227 & $\begin{array}{l}.74 \\
1\end{array}$ & .159 & .714 \\
\hline Following the news & & 3.82 & $\begin{array}{l}.01 \\
8\end{array}$ & .382 & $\begin{array}{l}.70 \\
2\end{array}$ & .279 & .124 \\
\hline Finding general information & & 3.72 & $\begin{array}{l}.02 \\
4\end{array}$ & .498 & $\begin{array}{l}.00 \\
5\end{array}$ & .631 & .000 \\
\hline $\begin{array}{l}\text { Finding specific information related } \\
\text { to courses }\end{array}$ & & 3.68 & $\begin{array}{l}.02 \\
4\end{array}$ & .512 & $\begin{array}{l}.01 \\
1\end{array}$ & .911 & .000 \\
\hline Making friends & & 3.62 & $\begin{array}{l}.02 \\
4\end{array}$ & .499 & $\begin{array}{l}.74 \\
5\end{array}$ & .473 & .220 \\
\hline Making a chat & & 3.62 & .24 & .499 & $\begin{array}{l}.74 \\
5\end{array}$ & .473 & .220 \\
\hline Making communications & & 3.61 & $\begin{array}{l}.02 \\
4\end{array}$ & .497 & $\begin{array}{l}.47 \\
7\end{array}$ & .777 & .146 \\
\hline Making discussion groups & & 3.56 & $\begin{array}{l}.02 \\
6\end{array}$ & .545 & $\begin{array}{l}.61 \\
9\end{array}$ & .565 & .035 \\
\hline Wasting time & & 3.17 & $\begin{array}{l}.04 \\
3\end{array}$ & .902 & $\begin{array}{l}.08 \\
9\end{array}$ & .253 & .000 \\
\hline Playing games & & 3.03 & $\begin{array}{l}.04 \\
2\end{array}$ & .882 & $\begin{array}{l}.47 \\
7\end{array}$ & .568 & .000 \\
\hline Completing class assignments & & 2.67 & $\begin{array}{l}.02 \\
7\end{array}$ & .566 & $\begin{array}{l}.82 \\
8\end{array}$ & .019 & .509 \\
\hline $\begin{array}{l}\text { Checking materials related to courses, } \\
\text { grades, etc. }\end{array}$ & & 2.63 & $\begin{array}{l}.02 \\
9\end{array}$ & .604 & $\begin{array}{l}.60 \\
3\end{array}$ & .045 & .603 \\
\hline Doing business & & 2.60 & $\begin{array}{l}.02 \\
9\end{array}$ & .599 & $\begin{array}{l}.90 \\
0\end{array}$ & .056 & .754 \\
\hline Seeking jobs & & 2.57 & $\begin{array}{l}.02 \\
9\end{array}$ & .600 & $\begin{array}{l}.42 \\
5\end{array}$ & .020 & .021 \\
\hline Watching movies/videos & & 2.31 & $\begin{array}{l}.04 \\
8\end{array}$ & $\begin{array}{l}1.01 \\
6\end{array}$ & $\begin{array}{l}.00 \\
4\end{array}$ & .255 & .000 \\
\hline Listening to music & & 1.85 & $\begin{array}{l}.03 \\
8\end{array}$ & .808 & $\begin{array}{l}.03 \\
9\end{array}$ & .670 & .000 \\
\hline Accessing library services & & 1.60 & $\begin{array}{l}.03 \\
0\end{array}$ & 639 & $\begin{array}{l}.00 \\
6\end{array}$ & .141 & .001 \\
\hline Dating someone & & 1.36 & $\begin{array}{l}.02 \\
5 \\
\end{array}$ & .520 & $\begin{array}{l}.08 \\
0 \\
\end{array}$ & .001 & .008 \\
\hline
\end{tabular}

RQ7. What are the positive and negative aspects of the students' use of apps at SVU's DLIS?

Smart phone users were asked to report their level of agreement or disagreement about some of the positive attitudes towards the use of apps. As shown in Table XXII, all students indicated very positive attitudes towards the use of apps as $100 \%$ of them were at least agree with the statement that smart phone apps allow for easy dissemination of information, provide too much information, increase the speed of 
finding information, help communication, convenient, secure, build confidence and reduce paper use. Of the 441 students, 39\% indicated that they have at least agreed that these apps are credible, followed by $38 \%$ as agree, $28 \%$ as no strong opinion, $21.1 \%$ as disagree and $11.8 \%$ as strongly disagree.

Table XXII.

Positive statements about the use of smart phone apps by students

\begin{tabular}{|c|c|c|c|c|c|}
\hline $\begin{array}{l}\text { Positive statement about smart } \\
\text { phone apps }\end{array}$ & $\begin{array}{l}\text { Strongly } \\
\text { agree } \\
(\%)\end{array}$ & $\begin{array}{l}\text { Agre } \\
\mathrm{e} \\
(\%)\end{array}$ & $\begin{array}{l}\text { No strong } \\
\text { opinion } \\
(\%)\end{array}$ & $\begin{array}{l}\text { Disagr } \\
\text { ee } \\
(\%)\end{array}$ & $\begin{array}{l}\text { Strongly } \\
\text { disagree } \\
(\%)\end{array}$ \\
\hline provide too much information & 45.4 & 54.6 & 0 & 0 & 0 \\
\hline reduce paper use & 44.7 & 55.3 & 0 & 0 & 0 \\
\hline are secure & 43.5 & 56.5 & 0 & 0 & 0 \\
\hline $\begin{array}{l}\text { allow for easy dissemination of } \\
\text { information }\end{array}$ & 42.6 & 57.4 & 0 & 0 & 0 \\
\hline build confident & 41.7 & 58.3 & 0 & 0 & 0 \\
\hline are convenient & 41.5 & 58.5 & 0 & 0 & 0 \\
\hline help communication & 41 & 59 & 0 & 0 & 0 \\
\hline $\begin{array}{l}\text { increase the speed of finding } \\
\text { information }\end{array}$ & 39.5 & 60.5 & 0 & 0 & 0 \\
\hline are credible & .7 & 38.3 & 28.1 & 21.1 & 11.8 \\
\hline
\end{tabular}

Through One-Way ANOVA, the study revealed that there is no a statistically significant difference at the p>.05 level between the demographic characteristics of students (age, gender \& class standing) and their positive attitudes towards the use of smart phone apps (Table XXIII).

Table XXIII.

ANOVA (shortened) by positive statements about smart phone apps \& students' demography through Mean, SE \& SD

\begin{tabular}{|c|c|c|c|c|c|c|c|}
\hline \multirow{2}{*}{$\begin{array}{l}\text { Positive statements } \\
\text { about the use of smart phone } \\
\text { apps }\end{array}$} & \multicolumn{4}{|c|}{ Statistics } & \multicolumn{3}{|c|}{ Level of Significance } \\
\hline & $\begin{array}{l}\mathrm{N} \\
(441)\end{array}$ & $\begin{array}{l}\text { Mea } \\
\mathrm{n}\end{array}$ & $\mathrm{SE}$ & SD & Age & $\begin{array}{l}\text { Gend } \\
\text { er }\end{array}$ & $\begin{array}{l}\text { Class } \\
\text { standing }\end{array}$ \\
\hline provide too much information & & 4.45 & .24 & $\begin{array}{l}.49 \\
8\end{array}$ & $\begin{array}{l}.27 \\
6\end{array}$ & .675 & .861 \\
\hline reduce paper use & & 4.45 & $\begin{array}{l}.02 \\
4\end{array}$ & $\begin{array}{l}.49 \\
8\end{array}$ & $\begin{array}{l}.58 \\
9\end{array}$ & .339 & .795 \\
\hline are secure & & 4.44 & $\begin{array}{l}.02 \\
4\end{array}$ & $\begin{array}{l}4.9 \\
6\end{array}$ & $\begin{array}{l}.43 \\
9\end{array}$ & .915 & .944 \\
\hline $\begin{array}{l}\text { allow for easy dissemination of } \\
\text { information }\end{array}$ & & 4.43 & $\begin{array}{l}.02 \\
4\end{array}$ & $\begin{array}{l}.49 \\
5\end{array}$ & $\begin{array}{l}.44 \\
0\end{array}$ & .960 & .926 \\
\hline build confident & & 4.42 & $\begin{array}{l}.02 \\
4\end{array}$ & $\begin{array}{l}.49 \\
4\end{array}$ & $\begin{array}{l}.72 \\
7\end{array}$ & .491 & .829 \\
\hline help communication & & 4.41 & $\begin{array}{l}.02 \\
3\end{array}$ & $\begin{array}{l}.49 \\
2\end{array}$ & $\begin{array}{l}.27 \\
5\end{array}$ & .620 & .325 \\
\hline are convenient & & 4.41 & $\begin{array}{l}.02 \\
3\end{array}$ & $\begin{array}{l}.49 \\
3\end{array}$ & $\begin{array}{l}.31 \\
6\end{array}$ & .863 & .841 \\
\hline $\begin{array}{l}\text { increase the speed of finding } \\
\text { information }\end{array}$ & & 4.39 & $\begin{array}{l}.02 \\
3\end{array}$ & $\begin{array}{l}.48 \\
9\end{array}$ & $\begin{array}{l}.53 \\
0\end{array}$ & .884 & .877 \\
\hline are credible & & 2.95 & .05 & 1.0 & .23 & .446 & .722 \\
\hline
\end{tabular}


Students were also asked to report their level of agreement or disagreement about some of the negative attitudes towards the use of smart phone apps. As shown in Table XXIV, 99.5\% of the students were at least agree with the statement that these apps are time consuming, followed by $99.4 \%$ who indicated that these apps are intimidating, $99.3 \%$ with at least agree that these apps are addictive, $99.1 \%$ with at least agree that these apps violate privacy, 99\% with at least agree that these apps require high language and technical skills, $64.7 \%$ who were agree that these apps are harmful, $20.6 \% \%$ who were agree that these apps "are frustrating" and $16.8 \% \%$ who were agree that these apps are harmful.

Table XXIV.

Negative statements about the use of smart phone apps by students

\begin{tabular}{|c|c|c|c|c|c|}
\hline $\begin{array}{l}\text { Negative statements about smart } \\
\text { phone apps }\end{array}$ & $\begin{array}{l}\text { Strongly } \\
\text { agree } \\
(\%)\end{array}$ & $\begin{array}{l}\text { Agre } \\
\mathrm{e} \\
(\%)\end{array}$ & $\begin{array}{l}\text { No strong } \\
\text { opinion } \\
(\%)\end{array}$ & $\begin{array}{l}\text { Disagr } \\
\text { ee } \\
(\%)\end{array}$ & $\begin{array}{l}\text { Strongly } \\
\text { disagree } \\
(\%)\end{array}$ \\
\hline are time consuming & 78.2 & 21.3 & .5 & 0 & 0 \\
\hline are addictive & 73.2 & 26.1 & .7 & 0 & 0 \\
\hline $\begin{array}{l}\text { require high skills (language and } \\
\text { technical skills) }\end{array}$ & 72.6 & 26.5 & .9 & 0 & 0 \\
\hline violate privacy & 71.7 & 27.2 & 1.1 & 0 & 0 \\
\hline are intimidating & 66.4 & 33.1 & .5 & 0 & 0 \\
\hline are harmful & 0 & 16.8 & 48.1 & 34 & 1.1 \\
\hline are frustrating & 0 & 20.6 & 48.8 & 29.3 & 1.4 \\
\hline
\end{tabular}

Through One-Way ANOVA, this study revealed that there is no a statistically significant difference at the $p>.05$ level between the students' age and their negative attitudes towards the use of apps. It also revealed that there is no a statistically significant difference between their gender and class standing and almost of these negative attitudes towards the use of apps. The study also revealed that there is a statistically significant difference between the students' gender and some of the negative aspects of the use of apps, such as that these apps require high skills $(p=.006)$ and are intimidating $(p=.041)$ as well as students' class standing and the violation of privacy that these apps may cause $(p=.003)$ (Table XXV).

Table XXV.

ANOVA (shortened) by negative statements about smart phone apps and students' demography through Mean, SE \& SD

\begin{tabular}{|c|c|c|c|c|c|c|c|}
\hline \multirow{2}{*}{$\begin{array}{l}\text { Negative statements } \\
\text { about the use of smart phone apps }\end{array}$} & \multicolumn{4}{|c|}{ Statistics } & \multicolumn{3}{|c|}{ Level of Significance } \\
\hline & $\mathrm{N}$ & $\begin{array}{l}\text { Mea } \\
\mathrm{n}\end{array}$ & $\mathrm{SE}$ & SD & Age & $\begin{array}{l}\text { Gend } \\
\text { er }\end{array}$ & $\begin{array}{l}\text { Class } \\
\text { standing }\end{array}$ \\
\hline are time consuming & 441 & 4.78 & $\begin{array}{l}.02 \\
0\end{array}$ & $\begin{array}{l}.42 \\
7\end{array}$ & $\begin{array}{l}.73 \\
2\end{array}$ & .219 & .826 \\
\hline are addictive & 441 & 4.73 & $\begin{array}{l}.02 \\
2\end{array}$ & $\begin{array}{l}.46 \\
2\end{array}$ & $\begin{array}{l}.58 \\
0\end{array}$ & .092 & .078 \\
\hline $\begin{array}{l}\text { require high skills (language and } \\
\text { technical skills) }\end{array}$ & 441 & 4.72 & $\begin{array}{l}.02 \\
2\end{array}$ & $\begin{array}{l}.47 \\
1\end{array}$ & $\begin{array}{l}.92 \\
9\end{array}$ & .006 & .643 \\
\hline violate privacy & 441 & 4.71 & $\begin{array}{l}.02 \\
3\end{array}$ & $\begin{array}{l}.48 \\
1\end{array}$ & $\begin{array}{l}.52 \\
7\end{array}$ & .052 & .003 \\
\hline are intimidating & 441 & 4.66 & $\begin{array}{l}.02 \\
3\end{array}$ & $\begin{array}{l}.48 \\
4\end{array}$ & $\begin{array}{l}.76 \\
4\end{array}$ & .041 & .232 \\
\hline
\end{tabular}




\begin{tabular}{llllllll}
\hline are frustrating & 441 & 2.89 & .03 & .73 & .29 & .534 & .598 \\
are harmful & & & 5 & 6 & 5 & & \\
& 441 & 2.80 & .03 & .71 & .23 & .703 & .952 \\
\hline
\end{tabular}

This study revealed that the most smart phone apps users trust in, as Table shows XXVI, was What's app, E-mail, Youtube, Facebook, Flickr and Twitter. In detail, 99.5\% of users confirmed that they "What's app", followed by "e-mail" (98.4\%), "Youtube" (96.8\%), "Facebook" (95.2\%), "Fliker" (95.1\%), “Twitter" (94.8\%), "Viber" (94.6\%), “Kik" (93.9\%), “Google mobile” (92.7\%), "Line” (91.2\%), "Google maps" (90.5\%), "Instgram" (90.1\%), "Tango" (89.8\%), "Skype" (88\%) and "Wikipedia mobile" (56\%) were at least trustful to them.

Table XXVI.

Trusting in apps by smart phone users

\begin{tabular}{|c|c|c|c|c|c|}
\hline $\begin{array}{l}\text { Trusting in smart } \\
\text { phone apps }\end{array}$ & $\begin{array}{l}\text { Strongly } \\
\text { trustful } \\
(\%)\end{array}$ & $\begin{array}{l}\text { Trustful } \\
(\%)\end{array}$ & $\begin{array}{l}\text { Neutral } \\
(\%)\end{array}$ & $\begin{array}{l}\text { Untrusted } \\
(\%)\end{array}$ & $\begin{array}{l}\text { Strongly } \\
\text { untrusted } \\
(\%)\end{array}$ \\
\hline E-mail app & 81.6 & 15.9 & 1.6 & 0 & 0 \\
\hline What's app & 66.4 & 33.1 & .5 & 0 & 0 \\
\hline Youtube & 62.6 & 34.2 & 3.2 & 0 & 0 \\
\hline Twitter & 60.5 & 34.2 & 3.9 & 1.4 & 0 \\
\hline Facebook & 58 & 37.2 & 3.2 & 1.6 & 0 \\
\hline Flickr & 58 & 37 & 3.2 & 1.8 & 0 \\
\hline Kik & 56.9 & 37 & 5.2 & .9 & 0 \\
\hline Viber & 56.7 & 36.1 & 3.4 & 1.8 & 0 \\
\hline Google mobile & 56.2 & 36.5 & 63 & .9 & 0 \\
\hline Google maps & 50.1 & 40.4 & 9.3 & .2 & 0 \\
\hline Instagram & 49.9 & 41 & 7.7 & 1.4 & 0 \\
\hline Line & 49.4 & 41.7 & 7.5 & 1.4 & 0 \\
\hline Tango & 48.8 & 41 & 8.8 & 1.4 & 0 \\
\hline Skype & 46.7 & 41.3 & 11.1 & .9 & 0 \\
\hline Wikipedia mobile & 6.6 & 49.2 & 38.8 & 5.2 & .2 \\
\hline
\end{tabular}

Through One-Way ANOVA, the study revealed that there is no a statistically significant difference at the $p>.05$ level between the students' age and their trust in Facebook, Viber, Flickr, Google maps, Instgram, Youtube, What's app, Wikipedia mobile, Line, Tango and Skype. The study also revealed that is no a statistically significant difference between the students' gender and their trust in E-mail, Facebook, Viber, Flickr, Google maps, Instgram, Twitter, Youtube, What's app, Wikipedia mobile, Line, Tango and Skype as well as the students' class standing and their trust in E-mail, Facebook, Viber, Flickr, Google maps, Instgram, Youtube, What's app, Wikipedia mobile, Line, Tango and Skype. On the other hand, the study revealed that there is a statistically significant difference at the $p>.05$ level between the students' age and their trust in Twitter $(p=.024)$. There is also a statistically significant difference between the students' gender and their trust in What's app $(p=.041)$ as well as their class standing and trust in $(p=.002)$ and Kik $(p=013)$ (Table XXVII).

Table XXVII.

ANOVA (shortened) by trusting in apps and students' demography through Mean, SE \& SD

\section{Statistics} Level of Significance 


\begin{tabular}{|c|c|c|c|c|c|c|c|}
\hline $\begin{array}{l}\text { Trusting in } \\
\text { apps }\end{array}$ & $\begin{array}{l}\mathrm{N} \\
(441)\end{array}$ & $\begin{array}{l}\text { Mea } \\
\mathrm{n}\end{array}$ & SE & SD & Age & $\begin{array}{l}\text { Gend } \\
\text { er }\end{array}$ & $\begin{array}{l}\text { Class } \\
\text { standing }\end{array}$ \\
\hline E-mail app & & 5.26 & $\begin{array}{l}.22 \\
8\end{array}$ & $\begin{array}{l}4.7 \\
83\end{array}$ & $\begin{array}{l}.89 \\
1\end{array}$ & .400 & .292 \\
\hline What's app & & 4.66 & $\begin{array}{l}.02 \\
3\end{array}$ & $\begin{array}{l}.48 \\
4\end{array}$ & $\begin{array}{l}.76 \\
4\end{array}$ & .041 & .232 \\
\hline Youtube & & 4.59 & $\begin{array}{l}.02 \\
9\end{array}$ & $\begin{array}{l}.55 \\
3\end{array}$ & $\begin{array}{l}.16 \\
2\end{array}$ & .440 & .344 \\
\hline Twitter & & 4.54 & $\begin{array}{l}.03 \\
0\end{array}$ & $\begin{array}{l}.63 \\
9\end{array}$ & $\begin{array}{l}.02 \\
4\end{array}$ & .363 & .002 \\
\hline Facebook & & 4.52 & $\begin{array}{l}.03 \\
0\end{array}$ & $\begin{array}{l}.64 \\
0\end{array}$ & $\begin{array}{l}.40 \\
7\end{array}$ & .979 & .554 \\
\hline Viber & & 4.52 & $\begin{array}{l}.03 \\
1\end{array}$ & $\begin{array}{l}.65 \\
4\end{array}$ & $\begin{array}{l}.78 \\
1\end{array}$ & .842 & .465 \\
\hline Flickr & & 4.51 & $\begin{array}{l}.03 \\
1\end{array}$ & $\begin{array}{l}.65 \\
0\end{array}$ & $\begin{array}{l}.32 \\
6\end{array}$ & .225 & .499 \\
\hline Kik & & 4.50 & $\begin{array}{l}.03 \\
0\end{array}$ & $\begin{array}{l}.64 \\
0\end{array}$ & $\begin{array}{l}.40 \\
0\end{array}$ & .481 & .013 \\
\hline $\begin{array}{l}\text { Google } \\
\text { mobile }\end{array}$ & & 4.48 & $\begin{array}{l}.03 \\
1\end{array}$ & $\begin{array}{l}.65 \\
7\end{array}$ & $\begin{array}{l}.06 \\
6\end{array}$ & 1.000 & .114 \\
\hline Google maps & & 4.40 & $\begin{array}{l}.03 \\
2\end{array}$ & $\begin{array}{l}.66 \\
4\end{array}$ & $\begin{array}{l}.30 \\
3\end{array}$ & .507 & .846 \\
\hline Instagram & & 4.39 & $\begin{array}{l}.03 \\
3\end{array}$ & $\begin{array}{l}.69 \\
0\end{array}$ & $\begin{array}{l}.69 \\
2\end{array}$ & .334 & .090 \\
\hline Line & & 4.39 & $\begin{array}{l}.03 \\
3\end{array}$ & $\begin{array}{l}.68 \\
6\end{array}$ & $\begin{array}{l}.40 \\
6\end{array}$ & .764 & .686 \\
\hline Tango & & 4.39 & $\begin{array}{l}.03 \\
3\end{array}$ & $\begin{array}{l}.70 \\
2\end{array}$ & $\begin{array}{l}.67 \\
9\end{array}$ & 262 & .074 \\
\hline Skype & & 4.34 & $\begin{array}{l}.03 \\
4\end{array}$ & $\begin{array}{l}.70 \\
8\end{array}$ & $\begin{array}{l}.32 \\
9\end{array}$ & .246 & .255 \\
\hline $\begin{array}{l}\text { Wikipedia } \\
\text { mobile }\end{array}$ & & 3.57 & $\begin{array}{l}.03 \\
4\end{array}$ & $\begin{array}{l}.68 \\
9\end{array}$ & $\begin{array}{l}.28 \\
2\end{array}$ & .476 & .116 \\
\hline
\end{tabular}

RRQ8. What are the most significant barriers that affect both use and non-use of apps students at SVU's DLIS?

Students were asked to report their level, among four scales given to them, of barriers that may affect their use of apps. They have given many varied answers ranging from "not significant" to "very significant". As shown in Table XXVIII, findings revealed that $51.9 \%$ of users indicated that the lack of "training to use different apps" and " appropriate smart phone apps" were not significant to them, followed by "Lack of the awareness of apps" (50.3\%), "Lack of time needed to access apps" (49.7\%), "Lack of language and technical skills needed for some apps" (48.8\%), "Lack of the connection to the Internet needed to access apps" $(48.3 \%$,), "Lack of the knowledge about apps" $(47.6 \%)$ and "Lack of adequate funds needed to get business apps" (46.9\%).

Table XXVIII.

Barriers to use smart phone apps by smart phone users

\begin{tabular}{lllll}
\hline & Very & Significa & Somewhat & $\begin{array}{l}\text { Not } \\
\text { Barriers to use smart phone apps }\end{array}$ \\
\hline \hline
\end{tabular}




\begin{tabular}{|c|c|c|c|c|}
\hline & $(\%)$ & $(\%)$ & $(\%)$ & $(\%)$ \\
\hline Lack of training to use different apps & 0 & 9.8 & 38.3 & 51.9 \\
\hline Lack of appropriate apps & 0 & 9.3 & 38.8 & 51.9 \\
\hline Lack of the awareness of apps & 0 & 10.9 & 38.8 & 50.3 \\
\hline Lack of time needed to access apps & 0 & 11.1 & 39.2 & 49.7 \\
\hline $\begin{array}{l}\text { Lack of language and technical skills needed } \\
\text { for some apps }\end{array}$ & 0 & 10.9 & 40.4 & 48.8 \\
\hline $\begin{array}{l}\text { Lack of the connection to the Internet needed } \\
\text { to access apps }\end{array}$ & 0 & 11. & 40.6 & 48.3 \\
\hline Lack of the knowledge about apps & 0 & 11.3 & 41 & 47.6 \\
\hline $\begin{array}{l}\text { Lack of adequate funds needed to get } \\
\text { business apps }\end{array}$ & 0 & 11.8 & 41.3 & 46.9 \\
\hline
\end{tabular}

Through One-Way ANOVA, the study revealed that there is no a statistically significant difference at the $p>.05$ level between the demographic characteristics (age and gender) of users and barriers to use apps. There is only a statistical relation between their class standing and training about the use of apps $(p=$ .007). On the other hand, there is a statistically significant difference at the $p>.05$ level between the age of smart phone apps non-users and adequate funds to get non-free apps $(p=.003)$, time to access apps $(p=$ $.016)$, training about using apps $(p=.000)$ and appropriate apps $(p=.021)$. There is also a statistically significant difference at the $p>.05$ level between the class standing of smart phone non-users and barriers to use apps, such as adequate funds $(p=.007)$, knowledge about apps $(p=.023)$, connection to the Internet $(p=.018)$ and training about using apps $(p=.000)$. (Table XXIX).

Table XXIX.

ANOVA (shortened) by Barriers to use apps and students' demography through Mean, SE \& SD

\begin{tabular}{|c|c|c|c|c|c|c|c|c|c|c|c|c|}
\hline \multirow[b]{3}{*}{$\begin{array}{l}\text { Barriers are due } \\
\text { to lack of }\end{array}$} & \multicolumn{6}{|c|}{ Smart phone apps users } & \multicolumn{6}{|c|}{ Smart phone apps non-users } \\
\hline & \multicolumn{3}{|c|}{ Statistics } & \multicolumn{3}{|c|}{ Sig. } & \multicolumn{3}{|c|}{ Statistics } & \multicolumn{3}{|c|}{ Sig. } \\
\hline & $\begin{array}{l}\mathrm{N} \\
(4 \\
41 \\
) \\
\end{array}$ & Mean & $\begin{array}{l}\mathrm{S} \\
\mathrm{D}\end{array}$ & Age & $\begin{array}{l}\mathrm{Ge} \\
\text { nde } \\
\mathrm{r}\end{array}$ & $\begin{array}{l}\text { Class } \\
\text { standing }\end{array}$ & $\begin{array}{l}\mathrm{N} \\
(92 \\
) \\
\end{array}$ & $\begin{array}{l}\text { Mea } \\
\mathrm{n}\end{array}$ & $\begin{array}{l}\text { S } \\
\text { D }\end{array}$ & Age & $\begin{array}{l}\text { Gen } \\
\text { der }\end{array}$ & $\begin{array}{l}\text { Class } \\
\text { standin } \\
\mathrm{g}\end{array}$ \\
\hline $\begin{array}{l}\text { Adequate funds to } \\
\text { get non-free apps }\end{array}$ & & 1.65 & $\begin{array}{l}.6 \\
8 \\
2\end{array}$ & .580 & $\begin{array}{l}.95 \\
2\end{array}$ & .840 & & 3.17 & $\begin{array}{l}.7 \\
35\end{array}$ & $\begin{array}{l}.00 \\
3\end{array}$ & .981 & .007 \\
\hline $\begin{array}{l}\text { The knowledge } \\
\text { about apps }\end{array}$ & & 1.64 & $\begin{array}{l}.6 \\
7 \\
7\end{array}$ & .103 & $\begin{array}{l}.97 \\
7\end{array}$ & .506 & & 2.63 & $\begin{array}{l}.5 \\
69\end{array}$ & $\begin{array}{l}.09 \\
3\end{array}$ & .765 & .023 \\
\hline $\begin{array}{l}\text { The connection to } \\
\text { the Internet }\end{array}$ & & 1.63 & $\begin{array}{l}.6 \\
7 \\
6\end{array}$ & .195 & $\begin{array}{l}.94 \\
1\end{array}$ & .505 & & 2.95 & $\begin{array}{l}.6 \\
35\end{array}$ & $\begin{array}{l}.11 \\
1\end{array}$ & .100 & .018 \\
\hline $\begin{array}{ll}\text { language } & \& \\
\text { technical skills } & \end{array}$ & & 1.62 & $\begin{array}{l}.6 \\
7 \\
4\end{array}$ & .353 & $\begin{array}{l}.34 \\
6\end{array}$ & .350 & & 2.73 & $\begin{array}{l}.6 \\
65\end{array}$ & $\begin{array}{l}.05 \\
5\end{array}$ & .255 & .138 \\
\hline $\begin{array}{l}\text { The awareness } \\
\text { about apps }\end{array}$ & & 1.61 & $\begin{array}{l}.6 \\
7 \\
6\end{array}$ & .321 & $\begin{array}{l}.58 \\
8\end{array}$ & .667 & & 2.59 & $\begin{array}{l}.5 \\
96\end{array}$ & $\begin{array}{l}.52 \\
0\end{array}$ & .260 & .240 \\
\hline $\begin{array}{l}\begin{array}{l}\text { Time to access } \\
\text { apps }\end{array} \\
\end{array}$ & & 1.61 & $\begin{array}{l}.6 \\
7 \\
\end{array}$ & .613 & $\begin{array}{l}.82 \\
0\end{array}$ & .960 & & 2.17 & $\begin{array}{l}.5 \\
26\end{array}$ & $\begin{array}{l}.01 \\
6\end{array}$ & .667 & .292 \\
\hline
\end{tabular}




\begin{tabular}{|c|c|c|c|c|c|c|c|c|c|c|}
\hline & & 8 & & & & & & & & \\
\hline $\begin{array}{ll}\text { Training } & \text { about } \\
\text { using apps } & \end{array}$ & 1.58 & $\begin{array}{l}.6 \\
6 \\
3\end{array}$ & .103 & $\begin{array}{l}.64 \\
6\end{array}$ & .007 & 2.87 & $\begin{array}{l}.7 \\
59\end{array}$ & $\begin{array}{l}.00 \\
0\end{array}$ & .570 & .000 \\
\hline Appropriate apps & 1.57 & $\begin{array}{l}6 \\
5 \\
7 \\
\end{array}$ & .271 & $\begin{array}{l}.97 \\
0\end{array}$ & .703 & 2.30 & $\begin{array}{l}.6 \\
07\end{array}$ & $\begin{array}{l}.02 \\
1\end{array}$ & .133 & .054 \\
\hline
\end{tabular}

\section{Discussions and conclusions}

This study, which is the first of its kind about university students in Egypt, tried to investigate the usage patterns and ownership of smart phone apps among students at the Library and Information Science (DLIS), the South Valley University (SVU). Based on the results of this study, smart phone users (82.7\%) at SVU's DLIS tended to be females aged between twenty one and twenty two years, and mostly junior students. On the other hand, smart phone non-users (17.3\%) tended to be also females aged between nineteen and twenty years, and mostly sophomore students. These findings are highly consistent with other surveys, such as Pearson Student Mobile Device Survey (2014), which showed that female students dominate smart phones use. Before moving to the profile of smart phone users, the researcher would like to draw attention to the reasons that led to the non-use of smart phone apps by some of the sampled students at SVU's DLIS. Time to access these apps, followed by inadequate funds needed to get business apps, the connection to the Internet, training about using apps, language \& technical skills, knowledge and awareness about apps as well as appropriate apps respectively, were at least significant to not use these apps among $92(17.3 \%)$ students of the total sample.

This study revealed a widespread use of smart phone apps by $441(82.7 \%)$ of students who were using smart phone apps. It is worthy mentioning that Egypt is ranked 19th globally in terms of possession of individuals with mobile phones. According to the Ministry of Communications and Information Technology (2012), the number of mobile subscriptions in Egypt reached 92.640.000 mobile users till July 2012. This means that the number of subscribers is greater than the number of people who up to 80.471.8690! However, smart phones make up 8.4\% of all mobile phone handsets in Egypt (Vallabhan, 2012). Such a high percentage in the use of smart phones among students at SVU's DLIS is very highly consistent with other relevant surveys, such as UCAS Media survey, conducted in 2014, and Pearson Student Mobile Device Survey, conducted by Harris Poll in 2014, which revealed that $82 \%$ and $83 \%$, respectively, of college students own smart phones. The highest percentage of smart phone users indicated that they had been using smart phones for four to five years. This may indicate that they have caught up with the beginnings of these devices in Egypt, which is witnessing a big demand in the sale of these devices and prepared by some specialists as a promising market in this regard. The largest number of students was described to be advanced users who heard first about these mobile devices through friends and the Web being one of the most ways to access Mobile Internet Technologies (MITs). Consistent with Yavari et al. (2009), the most frequent location of students' access to these apps was from home/dormitory and University campus, where the availability of information networks, particularly WiFi networks. Consistent with Alfawareh and Jusoh (2014), Song and Lee (2012) and Pearson Student Mobile Device Survey (2014), this study showed that a majority of smart phone users were using a single smart phone device and a few of them were just using two devices, and the most predominant and popular brand they own was Android, followed by iPhone, Blackberry and Windows. Although the price of these devices is relatively expensive in Egypt, but they are available in abundance, particularly Android devices like Samsung. The highest percentage of smart phone users indicated that they have from 21 to 25 apps followed by 11 to 20 apps and 26 to 30 apps. A very few number of them indicated that they have more 31 apps. Such a number is highly consistent with the world's average number (26) of downloaded apps by smart phone users (Michael, 2013). Regarding the usage patterns of smart phones among library and 
information science students, the findings of this study are highly consistent with the findings of Adomi's study (2006) as the two studies revealed that a majority of the students were using apps mainly for making communication with their family and friends as well as sending and receiving messages.

A large number of smart phone users at SVU's DLIS have been described to make excessive use of social apps, such as communication apps, messaging/texting apps and social networking sites, which were at the forefront of use. Other apps, such as entertainment apps, news apps, games apps, multimedia apps, education apps, health apps and Business apps respectively were also found to be mostly used by students. Chen and Denoyelles (2013) revealed that most popular apps favorited by university students were social networking, music, games, navigation, entertainment, photography, news, university apps, books, reference and productivity. 'The popularity of mobile devices among students and the availability of touch screen devices make mobile devices an ideal avenue for delivering content that can be accessed anywhere and everywhere, on the go" (TsoI and Dekhane, 2011, P. 543). For some students, smart phones have become a necessity and an addictive tool. In this regard, Baghianimoghadam et al. (2013) showed that nearly a quarter of students had tried to decrease their use of these devices, but were unsuccessful! Smart phone users in this study spend an average of five hours per day on using these apps, especially social networking apps. Such use per hours is close to the international trend, as some previous studies, such as Uys et al. (2012), showed that the average hours spent by students on their smart phones communicating and interacting with others was five hours per day.

A large number of smart phone users at SVU's DLIS widely adopted these devices, especially for communication purposes as most of the apps were described to be communication apps. The most used apps were Facebook, E-mail, Twitter, What's app, Youtube and Viber. Such use is very much moderate compared to other similar studies, such as the study of Dresselhaus and Shrode (2012), which helped to gain insight into where students stand regarding their use of mobile devices for academic activities in general and their desire for access to library resources and services in particular. However, such use is consistent with UCAS Media survey (2014), which indicated that nearly $60 \%$ of university students use their smart phones more to access social media. Smart phone users at SVU's DLIS used smart phones more for communication purposes than learning purposes. While these findings are not consistent with the study of Bomhold (2013), which indicated that students do use smart phone apps for more than communication and entertainment, where a significant number of them disclose using apps to find academic information on academic web sites using related search engines, they are consistent with the findings of Bicen and Kocakoyun (2013) and White and Mills's study (2012), which showed that students are increasingly adopting these mobile devices for communication purposes, but they are still reluctant to use them for educational purposes. However, this study revealed that some of SVU's DLIS students were using some of apps related to educational purposes, such as Google mobile, Facebook, E-mail, Twitter, Youtube, Wikipedia mobile and Instgram, but not on a regular basis. Sometime the academic institutions and libraries, as the case of SVU's libraries, fail to meet the needs of their patrons regarindg some specific information. Due to these failure and constraints, Anyanwu, Ossai-Onah and Nse (2012) showed that students using the libraries were using their smart phones for research occasionally. Findings also revealed that students were pushed to use smart phone devices for some reasons, such as the lack of relevant information sources in libraries, saving of time and cost of travelling to other libraries for research, low level of satisfaction derived from available resources as well as the lack of Internet facilities in libraries. While Abdul Karim, Darus and Hussin (2006) revealed that students' perceptions on the application of wireless hand services in the context of library and information services were found to be very positive, this study revealed, consistent with the study of Shonola and Joy (2014), that SVU's libraries, especially the DLIS's library, lack to services related to the use of mobile devices in terms of the lack of information infrastructure and communication network, such as Wi-Fi networks as well as inadequate fundings and regulatory issues. 
Smart phone users' perceive of ease and usefulness of the use of smart phone devices was noticeably. They indicated that the use of E-mail app, Google mobile, Facebook app What's apps, Kik, Twitter, Youtube, Google maps, Viber, Line, Skype, Tango, Instgram, Flickr and Wikipedia mobile, respectively, were found to be at least fairly easy to them. According to Davis (1989), perceived ease of use has been found to influence the usage of electronic devices, such as the computer. The easier a system is to use, the less effort will be needed to do tasks. In the context of smart phone devices, we can propose that if they are easy to use, they require less effort on the part of users, thereby increasing the likelihood of their adoption and usage. Bicen and Kocakoyun (2013) revealed that is the ease of using smart phones apps is the most important reason why users use these mobile devices. Additionally, smart phone users in this study indicated that the use of E-mail app Google mobile, What's app, Facebook, Youtube, Twitter, Viber, Instgram, Wikipedia mobile, Google maps, Kik, Skype, Line, Tango and Flickr, respectively, at least fairly useful to them, especially for the purpose of socialization more than learning. To some extent, this finding is confirmed by the study of Rhema and Sztendur (2013), which revealed that students perceive smart phones as a useful tool, but more for their supporting learning.

The main tasks done on smart phone devices by students at SVU's DLIS were for socializing. Students indicated that popular tasks and activities, such as sending and receiving messages, following the news, making communications, making chat, making friends, finding specific information, finding general information, making discussion groups, playing games, completing class assignments, checking materials related to courses, doing business, seeking jobs, watching movies, listening to music, accessing library services are important tasks accomplished by them through the use of these devices. Sharing Heo et al. (2010), most apps used by students at SVU's DLIS range from navigation software, services providing news and weather feeds, entertainment and games to apps allowing users to access internet services such as email, Wikipedia, YouTube, Facebook and other social networking apps. Such apps, which are known as mobile social networking apps, allow students to connect with each other as well as with others like family, relatives and friends. Sharing White and Mills's study (2012), which revealed that students' attitudes towards the use of smart phone apps, especially for learning purposes have become more positive, the current study indicated very positive attitudes towards the use of these apps. Students have at least agreed with the statement that smart phone apps allow for easy dissemination of information, provide too much information, increase the speed of finding information, help communication, convenient, secure, build confident and reduce paper use. However, a large number of students agreed also at least with the statement that these apps are time consuming, intimidating, addictive, violate privacy, require high language and technical skills, harmful and frustrating. Almost all students confirmed that they are at least trustful in some apps, such as What's app, E-mail, Youtube, Facebook, Flickr, Twitter, and Viber.

Barriers related to training to use apps, appropriate apps, lack of the awareness of apps, lack of time needed to access apps, lack of language and technical skills needed for some apps, lack of the connection to the Internet needed to access apps, lack of the knowledge about apps and lack of adequate funds needed to get business apps were at least significant to smart phone users when accessing and using these apps. Despite such barriers do not seem to prevent smart phone users using these apps for socializing, they might prevent them from employing these apps for other purposes like educational and academic purposes. "While there are many positives to the use of smart phones for educational purposes, there are still several obstacles to the implementation of mobile technology in the classroom". (White \& Mills, 2012). Anyanwu, Ossai-Onah and Nse (2012) found that students were pushed to use mobile devices, particularly smart phones, for some reasons, such as the lack of relevant information sources in libraries, saving of time and cost of travelling to other libraries for research, low level of satisfaction derived from available resources as well as the lack of Internet facilities in libraries. On the other hand, there were also barriers related to the use of smart phones, such as the high cost of downloading online resources, 
incompatibility of software/format of online resources as well as insecurity of sites, which causes damages to the phones.

\section{Recommendations for further research}

The findings of this study revealed several areas that need to be addressed by further studies. Such findings may be used as a foundation for other researchers who wish to study how MITs are used among university students, especially LISs' students. As much as possible, the researcher of this study tried to investigate all characteristics and aspects of using such kind of mobile technologies among students at SVU's DLIS that may affect their use. However, sharing Alfawareh and Jusoh (2014)'s recommendations, further studies are still needed to examine more additional characteristics of using these mobile devices, particularly for academic practice. Really, there is a need to better understand how these mobile devices can be used to contribute to student learning. This study tried to investigate students' perceptions towards the use of smart phone apps in general. However, further research may be needed to specify the relationship between the students' use of these apps and their academic performance.

Since some of the students surveyed in this study, especially those who were described as smart phone non-users, lacked awareness and knowledge about the capabilities and benefits of these devices, they should be provided with a convenient environment to encourage and motivate towards their use. Further research needed to examine the digital divide between smart phone non-users and users and to study why such disparity exists and possible solutions that could reduce this gap. In this regard SVU's DLIS should create a non-threatening environment to reduce students' anxiety about the use of such mobile devices, offer Mobile Internet Technologies (MITs) literacy courses and design training workshop to use these tools effectively. Similarly, SVU's libraries should design and provide students with facilities to use mobile devices. This is in turn may encourage mobile learning, which helps students personalize their smart phones to fit their interactions with others. In this regard, further research is needed to discover the possibility of the integration of mobile technologies in education and library-related activities. Dresselhaus and Shrode (2012) tried to explore the extent to which libraries offer mobile access, their future plans for mobile implementation and their opinions about whether and how mobile technologies may be useful to library patrons. Students should also be provided with the necessary assistance to improve and promote their language and computer skills towards such usage. This study also recommends using smart phone apps, especially education apps, as a teaching tool to host learning-related materials and activities. Additionally, future studies may compare experiences of instructors and students regarding the use of SNSs in educational practices. Furthermore, new studies may look at how communicational uses of social networks have influenced educational uses.

Since this study is the first one of its type conducted about the usage of smart phones by students at a library school by one of Egyptian library schools $(n=17)$, and in the light of its descriptive nature, the research methodology used in this study may be the most suitable research method to reach the population of the study. However, for further research examining and investigating more specific information about such or related topics, other research methods, such as qualitative and experimental research, could be designed and conducted to measure the effectiveness of mobile learning in various disciplines. Lastly, this survey research has its limitations; the sample included undergraduate students at only one university in Egypt. Future research could focus on varied contexts or samples, such as graduates or postgraduates, regions or countries. 


\section{References}

Abdul Karim, N. Darus, S. and Hussin, R. (2006), "Mobile phone applications in academic library services: a students' feedback survey”, Campus-Wide Information Systems, Vol. 23 No. 1, pp. 35-51.

Adomi, E. (2006), "Mobile phone usage patterns of library and information science students at Delta State University, Abraka, Nigeria”, Electronic Journal of Academic and Special Librarianship, Vol. 7 no. 1, available at http://southernlibrarianship.icaap.org/content/v07n01/adomi_e01.htm (accessed 23 December 2014).

Alfawareh, H. and Jusoh, S. (2014), "Smartphones usage among university students: Najran university case", International Journal of Academic Research Part B, Vol. 6, pp. 321-326.

Anyanwu, E., Ossai-Onah, O. and Nse, J. (2012), "Use of mobile phones for research among undergraduates in two polytechnic libraries in Imo State, Nigeria", The Information Manager Vol. 12 No. $1 \& 2$, pp. 52-55.

Bae, J. and Kim, S. (2014), "Research on educational use of smart-phone applications with smart clicker technique", Lecture Notes in Electrical Engineering Vol. 279, pp. 597-602.

Baghianimoghadam, M., Shahbazi, H., Boroojeni, D. and Baghianimoghadam, B. (2013), "Attitude and usage of mobile phone among students in Yazd University of medical science", Iranian Red Crescent Medical Journal, Vol. 15 No, pp. 752-754.

Bicen, H. and Kocakoyun, S. (2013), "The evaluation of the most used mobile devices applications by students", Procedia - Social and Behavioral Sciences, No. 89, pp. 756 - 760.

Bomhold, C. (2013), "Educational use of smart phone Technology. A survey of mobile phone application use by

Chen, B. and Denovelles, A. (2013), "Exploring students' mobile learning practices in higher education", available at http://www.educause.edu/ero/article/exploring-students-mobile-learning-practices-highereducation (accessed 1 February 2015).

Chen, J., Park, Y., \& Putzer, G. J. (2010), “An examination of the components that increase acceptance of smartphones among healthcare professionals", Electronic Journal of Health Informatics, Vol. 5 No. 2, pp. e16, pp. 1-12.

Chiu, D., Dukic, D. and Lo, P. (14), "Educational Use of Mobile Technologies Amongst Library \& Information Science (LIS) Students - a Comparative Study Between the University of Hong Kong and the University of Tsukuba", available at http://www.infotech.ac.cn/CN/.../downloadArticleFile.do?... (accessed 11 March 2015).

Davis, F. (1989), "Perceived usefulness, perceived ease of use, and users acceptance of information technology", MIS Quarterly, 13, pp. 319-339.

Department of Library and Information Science (DLIS). (2014), "Faculty of Arts, available at http://www.svu.edu.eg/faculties/arts/dep_Libraries.htm (accessed 11 March 2015).

Dresselhaus, A. and Shrode, F. (2012), "Mobile technologies \& academics: Do students use mobile technologies in their academic lives and are librarians ready to meet this challenge?", Information Technologies and Libraries, June, pp. 82-101. 
Duffy MJ. (2011), "Smartphones in the Arab spring. In: Steffens M, Smith R and McCombs A (eds) IPI Report: Media and money. Vienna: International Press Institute, pp. 53-56.

Dahlstrom, E. (2012), ECAR Study of Undergraduate Students and Information Technology, EDUCAUSE Center for Applied Research, 2012, available at https://net.educause.edu/ir/library/pdf/ERS1208/ERS1208.pdf (accessed 9 March 2015).

Ecycle Best (2015), "Smartphones as Tools for Education: Getting Smart with Smartphones" available at http://www.ecyclebest.com/resources/smartphones-as-tools-for-education (accessed 27 December 2014).

Encyclopedia2.thefreedictionary. (2015), "Smartphone app, available at http://encyclopedia2.thefreedictionary.com/smartphone+app (accessed 3 March 2015).

Gay, L. R. (1992), "Educational Research, competencies for analysis and application”, (4th ed.). New York: Macmillan.

Harris Poll. (2014), "Pearson student mobile device survey 2014", available at http://www.pearsoned.com/wp-content/uploads/Pearson-K12-Student-Mobile-Device-Survey-050914PUBLIC-Report.pdf (accessed 11 January 2015).

Heo, J. Terada, K.m Toyama, M. Kurumatani, S. Chen, E. (2010), "User demand prediction from application usage pattern in virtual smart phone", IEEE Second International Conference on Cloud Computing Technology and Science, pp. 449-455.

Hwang, G., Chen, B., Chu, H., \& Cheng, Z. S. (2012), "Development of a Web 2.0-based ubiquitous learning platform for schoolyard plant identification. Paper presented at the 2012 Seventh IEEE International Conference on Wireless, Mobile and Ubiquitous Technology in Education, available at http://ieeexplore.ieee.org.lcproxy.shu.ac.uk/stamp/stamp.jsp?arnumber=06185043 (accessed 22 February 2015).

Infoplease. (2015), "Egypt", available at http://www.infoplease.com/country/profiles/egypt.html (accessed 23 January 2015).

Jamal, J. Sedie, R. Abdul Haleem, K. and Hafiz, N. (2012), "Patterns of use of 'smart phones' among female Medical students and self-reported effects", Medical students and self-reported effects, Journal of Taibah University Medical Sciences, Vol. 7, pp. 45-49.

Kerlinger, F. (1986), "Foundations of behavioral research", New York: Holt, Rinehart and Winston.

Linsky, A. (1975), "Stimulating responses to mailed questionnaires: A review", Journal of Marketing Research, Vol. 12, pp. 440-453.

Mahmoodabad, S., Barkhordari, A., Nadrian, H., Moshiri, O. and Yavari, M. (2009), "Survey of ownership and use of mobile phones among medical science students in Yazd. Pakistan", Journal of Biological Sciences, Vol. 12, pp. 1430-1433.

Michael, H. (2013), "The average global smartphone user has downloaded 26 apps", available at http://www.phonearena.com/news/The-average-global-smartphone-user-has-downloaded-26-

apps_id47160

Ministry of Communications and Information Technology. (2012), ICT Indicators in Brief: August 2012 | Monthly Issue

Available at http://www.mcit.gov.eg/Upcont/Documents/Publications_1992012000_Eng\%20FlyerAugust2012-last.pdf (accessed 11 March 2015).

Number of mobile app downloads worldwide from 2009 to 2017 (in millions), available at http://www.statista.com/statistics/266488/forecast-of-mobile-app-downloads (accessed 30 January 2015).

Rhema, A. and Sztendur, E. (2013), "Using a mobile phone to support learning: Experiences of engineering students in Libya", Proceedings of Informing Science \& IT Education Conference (InSITE) pp. 215-238.

Richard, E. (2013), “The American college students cell phone survey”, College Student Journal, Vol. 47 No. 1, pp. 75-81. 
Sakamura, K., and Koshizuka, N. (2005), "Ubiquitous computing technologies for ubiquitous learning", Proceeding of the International Workshop on Wireless \& Mobile Technologies in Education, 11-18.

Seilhamer, R., Chen, B. and Sugar, A. (2013), "A framework for implementing mobile technology," in Handbook of Mobile Learning, Z. Zane Berge and Lin Muilenburg, eds. (Routledge), pp. 382-394.

Shin, D., Shin, Y, Choo, H., \& Beom, K. (2011), "Smartphones as smart pedagogical tools: Implications for smartphones as u-learning devices", Computers in Human Behavior, Vol. 27, No. 6, pp. 2207-2214.

Shonola, S. and Joy, M. (2014), "Barriers to m-learning in higher education institutions in Nigeria", Proceedings of ICERI2014 Conference17th-19th November 2014, Seville, Spain, pp. 3324-3332

Song, Y. and Lee, J. (2012), "Mobile device ownership among international business students: a road to the ubiquitous library", Reference Services Review, Vol. 40 No. 4, pp. 574-588.

South Valley University (SVU). (2014), available at http://www.svu.edu.eg/about/index.html (accessed 11 March 2015).

Srivastava, A. (2014), "2 billion smartphone users by 2015: 83\% of Internet usage from mobiles [Study], available at http://dazeinfo.com/2014/01/23/smartphone-users-growth-mobile-internet-2014-2017 (accessed 11 March 2015).

Tsoi, M. and Dekhane, S. (2011), "TsoiChem: A mobile application to facilitate student learning in organic chemistry", paper presented at the 11th IEEE International Conference on Advanced Learning Technologies, Athens, GA.

UCAS. (2014), "Eight out of ten fresher's have smart phones: Does student marketing now mean mobile marketing?" available at http://www.ucasmedia.com/2014/eight-out-ten-freshers-have-smartphones (accessed 21 February 2015).

undergraduate university students”, Program: electronic library and information systems, Vol. 47 No. 4, pp. 424-436.

UYS, W. et al. (2012), "Smartphone application usage amongst students at a South African University", IST-Africa 2012 conference proceedings. Paul cunningham and Miriam Cunningham (Eds). IIMC International Information Management Corporation.

Vallabhan, C. (2012), "Smartphones make up 8.4\% of Egypt's mobile phones", available at http://www.commsmea.com/12812-smartphones-make-up-84-of-egypts-mobile-phones (accessed 3 December 2012).

Viticci, F. (2012), “Apple reveals new 'All-time top apps' following 25 billion downloads”, Macstories, available at: www.macstories.net/news/apple-reveals-new-all-time-top-appsfollowing-25-billiondownloads (accessed 3 December 2012).

White, J. and Mills, D. (2012), "Examining attitudes towards and usage of Smartphone technology among Japanese university students studying EFL", CALL-EJ, Vol. 15, pp.1-15. 